\title{
ARTICLES
}

\section{Regulation of Emission of Greenhouse Gases and Hazardous Air Pollutants from Motor Vehicles}

\author{
Steven G. Davison*
}

\author{
TABle of Contents
}

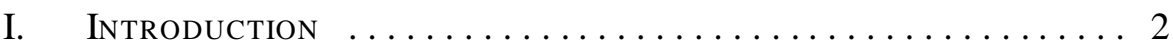

II. EPA's Decision Not to Regulate Carbon Dioxide Emissions

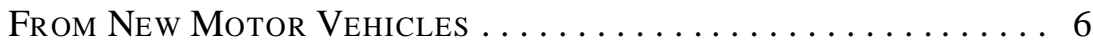

III. State Regulation of Greenhouse Gas Emissions From New

Motor Vehicles ........................ 34

IV. State Regulation of Greenhouse Gas Emis sions From In-use

On-Road Motor Vehicles . ................. 46

V. EPA Regulation of Emissions of Hazardous Air Pollutants From New Motor Vehicles . . . . . . . . . . . . . . . 52

VI. State and Local Government Regulation of Emissions of Hazardous Air Pollutants From Motor Vehicles . . . . . 58

VII. Conclusion ......................... 58

* Professor of Law, University of Baltimore School of Law; J.D. 1971, Yale Law School; B.S. 1968, Cornell University. 


\section{INTRODUCTION}

Emissions from motor vehicles of toxic and hazardous air pollutants, carbon dioxide, and other greenhouse gases ${ }^{1}$ — emissions that currently are not regulated under the federal Clean Air $\mathrm{Act}^{2}$ — are receiving increasing attention at both the federal and state government levels as government officials and members of the public express increasing concern that these substances may pose as much of a threat to public health and welfare as other pollutants from motor vehicles which currently are regulated under the Clean Air Act.

Many scientists are reporting a "25-year trend of rising global temperatures" and "other dramatic signs of global warming, such as the record shrinkage of the Arctic sea ice cover and unprecedented high ocean temperatures in the Gulf of Mexico." ${ }^{3}$ Many people attribute global warming to emissions of carbon dioxide and other greenhouse gases resulting from human activities such as the burning of fossil fuels by power plants and motor vehicles. ${ }^{4}$ Scientists recently have found that the year 2005 was the hottest year on record for the Northern Hemisphere, with temperatures approximately 1.3 degrees Fahrenheit above historical average temperatures. ${ }^{5}$

Many climatologists, along with policymakers in a number of countries, believe the rapid temperature rise over the past 50 years is heavily driven by the burning of fossil fuels and other human activities that have spewed carbon dioxide and other "greenhouse" gases into the atmosphere. A vocal minority of scientists say the warming climate is the result of a natural cycle. ${ }^{6}$

1. "Greenhouse gases" are gases which remain in the earth's lower atmosphere for long periods of time after being emitted at the earth's surface into the earth's lower atmosphere, trapping some of the infrared solar energy (heat) that radiates back into space from the earth's surface, resulting in increased warming of the earth's lower atmosphere and the earth's surface, much the way a human-made greenhouse increases the temperature within such a hot house. Massachusetts v. EPA, 415 F.3d 50, 56 (D.C. Cir. 2005).

2. $\quad 42$ U.S.C. $\S \S 7401-7671 q(2000)$.

3. Juliet Eilperin, World Temperatures Keep Rising With a Hot 2005, WASH. Post, Oct. 13, 2005, at A1.

4. Committee on the Science of Climate Change, National Research Council, Climate Change Science: An Analysis of Some of the Key Questions 2, 9 (2001).

5. Juliet Eilperin, 2005 Continues the Warming Trend, WASH. Post, Dec. 16, 2005, at A2. Scientists also report that worldwide temperatures in 2005 were either the highest or second-highest in recorded history. Id. If 2005 was the hottest year worldwide in recorded history, then the preceding three years were "the second, third and fourth warmest years on record." Eilperin, supra note 3, at A1, A7.

6. Eilperin, supra note 3, at A7. 
Motor vehicles (automobiles, light and heavy duty trucks, buses and motorcycles) that burn either gasoline or diesel fuel have long been known to emit into the ambient (outdoor) air large amounts of carbon monoxide, particulate matter, hydrocarbons, and oxides of nitrogen. These pollutants can adversely affect public health, particularly when thousands of motor vehicles are emitting such pollutants in a particular area. ${ }^{7}$

However, motor vehicles also emit large amounts of greenhouse gases and hazardous air pollutants, but these emissions from motor vehicles are not presently regulated under the Clean Air Act. Carbon dioxide is the greenhouse gas that is emitted in the largest amounts in both the United States and in other parts of the world. Although the largest amount of carbon dioxide probably is emitted from stationary fossil-fuel burning electric utility generating plants, the second largest amount of carbon dioxide probably is emitted by motor vehicles that burn gasoline and diesel fuel. In 2003 automobiles and light duty trucks in the United States emitted into the ambient air more than 317 million metric tons of carbon dioxide. ${ }^{8}$

Motor vehicles also emit three other greenhouse gases: methane, nitrous oxide, and hydrofluorocarbons. While hydrofluorocarbons are emitted from a motor vehicle's air conditioner, methane and nitrous oxide, like carbon dioxide, are byproducts of the combustion of gasoline and other fossil fuels, although the amount of methane and nitrous oxide emitted from a motor vehicle is also influenced by the design of the automobile's catalytic converter. ${ }^{9}$ In 1999 carbon dioxide emissions accounted for over ninety-four percent of transportation (motor vehicle) greenhouse gas emissions, with nitrous oxides accounting for four percent, hydrofluorocarbons one percent, and methane less than one percent. ${ }^{10}$

7. Carbon monoxide and PM-10 particulate matter (particulate matter less than 10 microns in diameter) are pollutants that have been listed as criteria pollutants under section 108 of the Clean Air Act, 42 U.S.C. $\$ 7408$ (2000), because the EPA Administrator found that emissions of those pollutants "cause or contribute to air pollution which may reasonably be anticipated to endanger public health or welfare." Id. at $\$ 7408(\mathrm{a})(1)(\mathrm{A})$. Emissions of hydrocarbons/volatile organic compounds and oxides of nitrogen contribute to the formation of ozone (a pollutant also listed as a criteria pollutant under section 108 of the Clean Air Act), a photochemical oxidant that is a principal component of smog (which causes significant harm to human beings, particularly in urban areas).

8. John DeCiccoet al., Envtl. Def., Automakers' Corporate Carbon Burdens, Executive Summary 2 (2005); Steven D. Cook, Carbon Dioxide from Cars Rises 25 Percent in 13 Years, 36 Env't Rep. (BNA) 1655 (Aug. 12, 2005).

9. Control of Emissions from New Highway Vehicles and Engines, 68 Fed. Reg. 52,922, 52,931 (Sept. 8, 2003).

10. Id. 
In recent years the concentrations of greenhouse gases in the earth's atmosphere have been increasing as the result of human activities such as the burning of fossil fuels and tropical deforestation. ${ }^{11}$ Many people believe that:

motor vehicle emissions of greenhouse gases contribute to global warming and that global warming in turn is causing a host of serious problems, likely including increased flash flood potential in the Appalachians, degraded water quality and reduced water supply in the Great Lakes, sea-ice melting and permafrost thawing in Alaska, reduced summer snow-pack runoff in the Rockies, extreme water resource fluctuations in Hawaii, and rising sea levels combined with higher storm surges along the coasts of Puerto Rico, the Virgin Islands and some eastern states. ${ }^{12}$

In addition, global warming caused by greenhouse gas emissions may result in "increased likelihood of drought, greater heat stress in urban areas . . . and disruption to many U.S. ecosystems [including wetlands, forests, grasslands, rivers, and lakes]." ${ }^{13}$ Furthermore, a number of scientists are contending that recent Hurricane Katrina was more severe than otherwise would have been the case because of increased temperatures of water in the Gulf of Mexico due to global warming caused by greenhouse gases. ${ }^{14}$

11. Massachusetts v. EPA, 415 F.3d 50, 62 (D.C. Cir. 2005) (Tatel, J., dissenting).

12. Id. at 61 (Tatel, J., dissenting).

13. Id. at 64 (Tatel, J., dissenting).

14. Juliet Eilperin, Severe Hurricanes Increasing, Study Finds, WASH.Post, Sept. 16, 2005, at A13. Other scientists contend, however, that the recent increase in the number and severity of hurricanes is due to natural fluctuations over long periods of time due to changes in currents and salinity of ocean waters. Peter Whoriskey, The Gathering Winds: A Rise in Deadly Storms Since '95 has Researchers Worried About the Future, WAsh. Post, Nov. 27, 2005, at A16.

The World Health Organization and some other scientists recently reported that global warming and climate change caused by greenhouse gases each year may directly contribute worldwide to 150,000 deaths and five million illnesses (including malaria, malnutrition, diarrhea, and dengue fever), with the areas most at risk including sub-Saharan Africa, areas on the coast of the Indian Ocean, the coastal areas of South Asia, and the areas of South and Central America on the coast of the Pacific Ocean. Juliet Eilperin, Climate Shift Tied to 150,000 Fatalities, WASH. Post, Nov. 17, 2005, at A20. These public health effects of global warming are disproportionately affecting poor countries which do not emit substantial amounts of greenhouse gases. Id. Developed countries that emit substantial amounts of greenhouse gases may experience increases in heat-related deaths in the future due to global warming. Climate Change: Global Warming Linked to Higher Mortality, Daily Env't Rep. (BNA) A7 (Nov. 17, 2005), at http:// pubs.bna.com/ip/bna/DEN.NSF/eh/a0b1z9e7r6 (last accessed Nov. 21, 2005) (“[M] odels suggest heatrelated deaths in California will more than double by 2100.”). "Global warming—with an accompanying rise in floods and droughts-is fueling the spread of epidemics in areas unprepared for diseases, say many health experts worldwide. Mosquitoes, ticks, mice and other carriers are surviving warmer winters and expanding their range, bringing health threats with them." Doug Struck, Climate Change Drives Disease to New Territory, WASH. Post, May 5, 2006, at A16. West Nile virus, a disease first identified in Africa in 1937 and that is spread by a common type of mosquito, first appeared on the North American continent seven years ago and since then has killed more than 800 people and infected 21,000 people in the U.S. and Canada. Id. 
Motor vehicles, the leading source of emissions into the ambient air of pollutants characterized as toxic or hazardous (because of threats of substantial harm to human health or the environment) "each year emit[] 168,000 tons of benzene, 83,000 tons of formaldehyde, 23,500 tons of 1,3 butadiene, and 28,700 tons of acetaldehyde." ${ }^{15}$ The United States Environmental Protection Agency (EPA) reportedly has acknowledged that these emissions of hazardous air pollutants from motor vehicles expose more than one hundred million Americans to a cancer risk that exceeds the EPA's "one-in-one million lifetime benchmark." 16

Emissions of hydrocarbons, carbon monoxide, oxides of nitrogen and particulate matter from both new and on-road in-use motor vehicles have been regulated under the Clean Air Act since the mid-1970s. Only recently has public attention begun to focus on regulation of emissions from motor vehicles of carbon dioxide, other greenhouse gases, and air pollutants characterized as toxic or hazardous under the Clean Air Act.

In Part II, this Article first will analyze a recent court judgment upholding a decision by the EPA Administrator not to regulate the emissions of carbon dioxide and other greenhouse gases from new motor vehicles under the Clean Air Act, principally on the ground that greenhouse gases are not "air pollutants" whose emissions can be regulated under the Clean Air Act. It concludes that the EPA Administrator has incorrectly interpreted the Clean Air Act in this manner, and that the EPA Administrator should adopt regulations under the Clean Air Act to regulate the emissions of greenhouse gases from new motor vehicles. This EPA regulation could be identical to, or modeled after, regulations recently adopted by the California Air Resources Board which will require the reduction of greenhouse gas emissions from new motor vehicles sold in California beginning with the 2009 model year.

The Article in Part III then analyzes California's regulations that will require reduction of greenhouse gas emissions from new motor vehicles beginning with the 2009 model year. This Part concludes that both the Clean Air Act and the federal Energy Policy and Conservation Act's Corporate Average Fuel Economy (CAFE) standards preempt California and other states from regulating the emissions of carbon dioxide and other greenhouse gases from new motor vehicles, unless the EPA Administrator grants California a

15. Pamela Najor, EPA, Groups Discuss Settlement of Lawsuit Seeking Controls on Mobile Toxic Emissions, 36 Env't Rep. (BNA) 1341 (July 1, 2005).

16. Steven D. Cook, EPA Agrees to Deadline for Controlling Hazardous Air Pollutants From Vehicles, 36 Env't Rep. (BNA) 1551 (July 29, 2005). 
waiver under the Clean Air Act. The EPA Administrator is unlikely to grant this waiver, even though the Clean Air Act appears to require him to do so.

Part IV examines state and local regulation of greenhouse gas emissions from in-use on-road motor vehicles, concluding that they are not preempted by the Clean Air Act. However, state and local governments are unlikely to exercise this authority because those vehicles would have to have their highway speeds or mileage reduced or undergo expensive retrofitting in order to reduce their greenhouse gas emissions.

Parts V and VI analyze the authority of the EPA and the states under the Clean Air Act to establish emission standards for toxic and hazardous air pollutants emitted from new and in-use on-road motor vehicles. This section concludes that although the EPA has declined to characterize carbon dioxide and other greenhouse gases as Clean Air Act hazardous air pollutants, the EPA is required to adopt standards under the Clean Air Act to regulate emissions from new motor vehicles of other pollutants that are characterized as toxic and hazardous air pollutants. The Article concludes in Part VII that states are preempted by the Clean Air Act from regulating emissions of hazardous air pollutants from new motor vehicles, although states have authority under the Clean Air Act to regulate the emissions of hazardous air pollutants from in-use on-road motor vehicles.

\section{EPA's Decision Not to Regulate Carbon Dioxide Emissions From New Motor Vehicles}

Although the Clean Air Act does not give the EPA nor the EPA Administrator any authority to regulate emissions of greenhouse gases from in-use on-road motor vehicles or to require owners or users of in-use on-road motor vehicles to undertake actions to reduce emissions of greenhouse gases from those vehicles, ${ }^{17}$ section 202(a)(1) ${ }^{18}$ of the Clean Air Act does give the EPA Administrator "general authorization" to adopt regulations to control emissions of air pollutants from new motor vehicles. ${ }^{19}$

17. The case of Sierra Club v. EPA, 325 F.3d 374 (D.C. Cir. 2003), points out that under the Clean Air Act the EPA only has authority "[i]n a small number of cases" to control emissions from in-use on-road motor vehicles. These situations include authorizing the EPA to issue regulations for the "control of rebuilding practices" for heavy duty engines per 42 U.S.C. $\$ 7521$ (a)(3)(D), and for retrofitting certain urban buses under 42 U.S.C. § 7554(d). It does not authorize the EPA Administrator to adopt regulations to control emissions of greenhouse gases from in-use on-road passenger automobiles and other categories of in-use on-road motor vehicles. Sierra Club, 325 F.3d at 381-82.

18. 42 U.S.C. $\$ 7521(a)(1)(2000)$.

19. Sierra Club v. EPA, 325 F.3d 374, 381 (D.C. Cir. 2003). 
However, the EPA Administrator in late 2003 denied a petition requesting that the EPA adopt standards under section 202(a)(1 $)^{20}$ of the Clean Air Act to regulate the emissions of carbon dioxide and other greenhouse gases from new motor vehicles, on the grounds that he did not have authority under section 202(a)(1) to regulate greenhouse gas emissions from new motor vehicles and that, even if he did have such statutory authority, he did not believe that it was appropriate to do so at the time ${ }^{21}$. In reaching this decision, the EPA Administrator followed a memorandum of the EPA's General Counsel, in which the Counsel concluded that the Clean Air Act "does not authorize regulation to address climate change," and withdrew a 1998 memorandum by a previous EPA General Counsel that reached a contrary conclusion. $^{22}$

In response to a judicial challenge to this EPA decision that was brought by twelve states, three cities, one American territory, and a number of environmental organizations, a majority of a divided three judge panel of the United States Court of Appeals for the District of Columbia held, in Massachusetts $v$. EPA, ${ }^{23}$ that the EPA Administrator properly exercised his discretion under section 202(a)(1) of the Clean Air Act in denying this petition. ${ }^{24}$

Section 202(a)(1) of the Clean Air Act provides that, except as otherwise provided by section 202(b), ${ }^{25}$ the EPA Administrator:

shall by regulation prescribe (and from time to time revise) . . . standards applicable to the emission of any air pollutant from any class or classes of new motor vehicles or new motor vehicle engines, which in his judgment cause, or contribute to, air pollution which

20. Id.; 42 U.S.C. $§ 7521(\mathrm{a})(1)$. 2003).

21. Control of Emissions from New Highway Vehicles and Engines, 68 Fed. Reg. 52,922 (Sept. 8,

22. Id. at 52,925 .

23. Massachusetts v. EPA, 415 F.3d 50 (D.C. Cir. 2005), reh'g denied, 2005 U.S. App. LEXIS 26560 (D.C. Cir. 2005), reh'g en banc denied, 433 F.3d 66 (D.C. Cir. 2005), cert. granted, 2006 U.S. LEXIS 4910 (U.S. June 26, 2006) (No. 05-1120). Judge Tatel, joined by Judge Rogers, dissented from the denial of the petition for rehearing en banc, arguing that the issue of global warming raised by the case presents an issue of exceptional importance that makes en banc review appropriate and that "the panel's judgment permitted the EPA to consider policy matters unconnected to the standard set by Clean Air Act section 202(a)(1) ... and to ignore record evidence of impending public harm and to refuse altogether to assess related risks." 433 F.3d at 67-68.

24. Massachusetts v. EPA, 415 F.3d 50 (D.C. Cir. 2005).

25. 42 U.S.C $\$ 7521$ (b) (2000). Section 202(b) established specific numerical emissions standards, expressed in terms of grams of pollutants emitted per vehicle mile, for carbon monoxide, hydrocarbons and oxides of nitrogen for certain model year new motor vehicles and engines. 
may reasonably be anticipated to endanger public health or welfare. Such standards shall be applicable to such vehicles and engines for their useful life. ${ }^{26}$

Except with respect to imported vehicles or engines, the terms "new motor vehicle" and "new motor vehicle engine" are defined by section $216(3)^{27}$ of the Clean Air Act as those for which "the equitable or legal title to which has never been transferred to the ultimate purchaser." 28

Section $302(\mathrm{~g})^{29}$ of the Clean Air Act further provides that " $[\mathrm{t}]$ he term 'air pollutant' means any air pollution agent or combination of such agents, including any physical, chemical, biological, radioactive . . . substance or matter which is emitted into or otherwise enters the ambient air." 30 Section 302(h) $)^{31}$ provides that:

[a]11 language referring to effects on welfare includes, but is not limited to, effects on soils, water, crops, vegetation, manmade materials, animals, wildlife, weather, visibility, and climate, damage to and deterioration of property, and hazards to transportation, as well as effects on economic values and personal comfort and well-being, whether caused by transformation, conversion, or combination with other pollutants. ${ }^{32}$

Section 202(b)(1) of the Clean Air Act, however, does not specify either the level at which the EPA Administrator should set a standard for a particular pollutant under the section or the substantive criteria that he should consider in setting a standard for a particular air pollutant. Although section 202 specifies the level at which standards for different classes of motor vehicles

26. Id. at $\$ 7521$ (a)(1). For light duty vehicles, light duty vehicle engines, and light duty trucks (up to $3,750 \mathrm{LVW}$ and up to $6,000 \mathrm{lbs}$. GWR), "useful life" is defined as a period of use of five years or fifty thousand miles (or the equivalent), whichever occurs first, except that "useful life" is defined as the period of ten years or one hundred thousand miles (or the equivalent), whichever occurs first, in the case of any requirement of section 202 of the Clean Air Act which first becomes applicable after November 15, 1990. Id. at $\$ 7521(\mathrm{~d})$. The "useful life" for any other motor vehicle or motor vehicle engine (other than motorcycles or motorcycle engines) is the same as for light duty vehicles, unless the EPA Administrator determines that a greater period of use or mileage is appropriate. The EPA Administrator is to determine the period of use for the "useful life" for any motorcycle or motorcycle engine. Id.

27. 42 U.S.C. $\$ 7550(3)$.

28. Under this definition, a vehicle or en gine no longer is new when it leaves a retail showroom after being sold to the ultimate user. Engine Mfrs. Ass'n v. EPA, 88 F.3d 1075, 1084 (D.C. Cir. 1996). In the case of imported vehicles or engines, the terms "new motor vehicle" and "new motor vehicle engine" are defined as ones "manufactured after the effective date of a regulation issued under section [202 of the Clean Air Act] which is applicable to such vehicle or engine (or which would be applicable to such vehicle or engine had it been manufactured for importation into the United States)." 42 U.S.C. § 7550(3).

29. 42 U.S.C. $\$ 7602(\mathrm{~g})$.

30. $I d$.

31. 42 U.S.C. $\$ 7602(\mathrm{~h})$.

32. Id. 
should be set for some specified model years for emissions of hydrocarbons, carbon monoxide, oxides of nitrogen, and particulate matter, ${ }^{33}$ section 202 does not specify the level at which the EPA Administrator should set new motor vehicle emissions standards for carbon dioxide or other greenhouse gases (other than nitrous oxides). ${ }^{34}$

However, since the EPA Administrator is required to set standards under section 202(a)(1) for emissions of a air pollutants from new motor vehicles which in his judgment cause, or contribute to, air pollution which may reasonably be anticipated to endanger public health or welfare, section 202(a)(1) should be interpreted as implicitly requiring him to set a standard for emissions of carbon dioxide and other greenhouse gases at a level that will not endanger public health or welfare, taking into account the availability of requisite technology and the costs of compliance with the standard.

A section 202(a)(1) standard for emissions of greenhouse gases from new motor vehicles should be a standard that can be met with available technology and at a reasonable cost, because section 202(a)(2) provides that any "[a]ny regulation prescribed under [section 202(a)(1)] (and any revision thereof) shall take effect after such period as the Administrator finds necessary to permit the development of the requisite technology, giving appropriate consideration to the cost of compliance within such period." 35

One basis for the EPA's rejection of the petition, seeking to have the EPA set standards under section 202(a)(1) of the Clean Air Act for emissions of

33. 42 U.S.C. $\S \S 7521(a)(3),(b),(g),(h),(i),(j),(f),(n)$.

34. Section 202 specifies emission standards for oxides of nitrogen (which include nitrous oxide) for specified model years. Section 206 establishes a system for the testing of prototypes of new motor vehicles and new motor vehicle engines, and of new motor vehicles and engines under production on assembly lines, to determine if they comply with section 202 standards and EPA regulations promulgated under section 202. If the EPA determines that a tested prototype complies with the section 202 standards, it issues a certificate of conformity for that vehicle or engine to the manufacturer. 42 U.S.C. $\$ 7525(a)(1)$. The sale of a new motor vehicle or engine is unlawful without such a certificate of conformity. 42 U.S.C. $\S 7522(a)(1)$. Section 207 of the Clean Air Act imposes defect and performance warranties on manufacturers of new motor vehicles and engines. 42 U.S.C. \$ 7541; Motor \& Equip. Mfrs. Ass'n v. EPA, 627 F.2d 1095, 1102-03 (D.C. Cir. 1979). The defect warranty, 42 U.S.C. § 7541(a), requires manufacturers to warrant to purchasers that each new motor vehicle or engine is designed, manufactured and equipped to conform to section 202 standards and is free of defects in materials and workmanship which would cause a motor vehicle or engine to fail to conform to the standards for its useful life (as defined under section 202 (d) of the Act, 42 U.S.C. $\$ 7521(\mathrm{~d})$ ). The performance warranty, 42 U.S.C. $\S 7541$ (b), requires a manufacturer to be responsible for the costs of remedying any failure of an emission control device or system in the vehicle or engine that results in a failure to conform with section 202 standards during the warranty period defined by section 207(i), 42 U.S.C. $\$ 7541$ (i), if the vehicle or engine has been maintained in accordance with the manufacturer's written maintenance instructions required by section 207(c)(3), 42 U.S.C. $\$ 7541(c)(3)$.

35. 42 U.S.C. $\$ 7521(a)(2)$. 
carbon dioxide from new motor vehicles, was that the EPA does not have statutory authority under section 202(a)(1) to regulate greenhouse gas emissions from new motor vehicles because emissions of greenhouse gases (such as carbon dioxide, methane, nitrous oxides and hydrofluorocarbons) are not emissions of "air pollutants" within the meaning of section 202(a)(1) of the Clean Air Act. ${ }^{36}$

Judge Randolph held in Massachusetts $v$. EPA that the EPA Administrator properly exercised his discretion in denying the petition. $\mathrm{He}$ assumed "arguendo that EPA has statutory authority to regulate greenhouse gases from new motor vehicles," ${ }^{37}$ but held that "the EPA Administrator properly exercised his discretion under $\S 202(a)(1)$ [of the Clean Air Act] in denying the petition for rulemaking" ${ }^{38}$ and therefore denied four of the petitions for review of the EPA Administrator's decision and dismissed four other petitions for review of the EPA Administrator's decision. ${ }^{39}$ Judge Sentelle dissented in part, in Massachusetts v. EPA, on the ground that the petitioners did not have standing to sue ${ }^{40}$ but he concurred in the judgment to deny four petitions for review and to dismiss four others. ${ }^{41}$

In dissent, however, Judge Tatel asserted that the EPA does have statutory authority under section 202(a)(1) of the Clean Air Act to set standards for greenhouse gas emissions from new motor vehicles ${ }^{42}$ and that the EPA improperly exercised its discretion under section 202(a)(1) in deciding not to set standards for carbon dioxide emissions from new motor vehicles. ${ }^{43}$

Judge Tatel, citing Chevron U.S.A., Inc. v. Natural Resources Defense Council, ${ }^{44}$ initially noted that in interpreting how a federal statute applies to "the precise question at issue" a court must give effect to the intention of

36. Control of Emissions From New Highway Vehicles and Engines, 68 Fed. Reg. 52,922, 52,928 (Sept. 8, 2003).

37. Massachusetts v. EPA, 415 F.3d 50, 56 (D.C. Cir. 2005).

38. Id. at 58 .

39. Id. at 58-59. The four petitions that were dismissed challenged the memorandum of the EPA's General Counsel upon which the EPA Administrator had relied in denying the petition for rulemaking under section 202(a)(1). Id. at 54. Judge Randolph indicated that this memorandum of the EPA General Counsel was not "final action" of the EPA Administrator that was subject to judicial review under section 307(b)(1), 42 U.S.C. § 7607(b)(1), of the Clean Air Act. 415 F.3d at 54.

Judge Randolph also discussed whether any of the petitioners had standing to bring the challenge to the EPA Administrator's denial of the petition for rulemaking. 415 F.3d at 55-57. However, "Judge Randolph [did] not resolve whether petitioners [had] standing." Id. at 61 (Tatel, J., dissenting).

40. Id. at 59-60 (Sentelle, J., dissenting in part and concurring in the judgment).

41. Id. at 60,61 .

42. 415 F.3d at 61-62, 67-68 (Tatel, J., dissenting).

43. Id. at $62,81,82$.

44. 467 U.S. 837 (1984). 
Congress on that question, with the inquiry beginning with the statute's plain language. ${ }^{45} \mathrm{He}$ then reasoned that the "exceedingly broad language" of the Clean Air Act's previously-quoted definition of "air pollutant" (in section $302(\mathrm{~g})^{46}$ of the Clean Air Act) "plainly covers [greenhouse gases] emitted from motor vehicles: they are "physical [and] chemical . . . substances or matter . . . emitted into . . . the ambient air." " 47 Judge Tatel did not mention the EPA Administrator's argument ${ }^{48}$ that in order for a substance to be an "air pollutant" under section 302(g)'s definition "it must be an 'agent' of 'air pollution." "However, the EPA Administrator did not explain in his decision how he defines "agent" and why carbon dioxide and other greenhouse gases are not "agents" of "air pollution" within the meaning of section $302(\mathrm{~g})$ of the Clean Air Act.

In support of his conclusion that greenhouse gases plainly are "air pollutants" under the Clean Air Act, Judge Tatel also noted ${ }^{49}$ that section 103(g) ${ }^{50}$ added to the Clean Air Act in 1990, "explicitly included [carbon dioxide] in a partial list of "air pollutants," in a provision instructing the EPA Administrator to conduct research on "nonregulatory strategies and technologies for preventing or reducing multiple air pollutants, including sulfur oxides, nitrogen oxides, heavy metals, PM-10 (particulate matter), carbon monoxide, and carbon dioxide, from stationary sources, including fossil fuel power plants. ${ }^{, 51}$ Judge Tatel, however, did not mention, as did the EPA Administrator ${ }^{52}$ in his decision not to regulate greenhouse gas emissions under section 202(a)(1) of the Clean Air Act, that section 103(g) provides that "[n]othing in this subsection shall be construed to authorize the imposition on any person of air pollution control requirements." ${ }^{53}$ This provision, however, does not prohibit the EPA Administrator from imposing carbon dioxide air pollution control requirements under other sections of the Clean Air Act.

On the basis of this analysis of the plain language of the Clean Air Act, Judge Tatel reasoned that both a court and an agency:

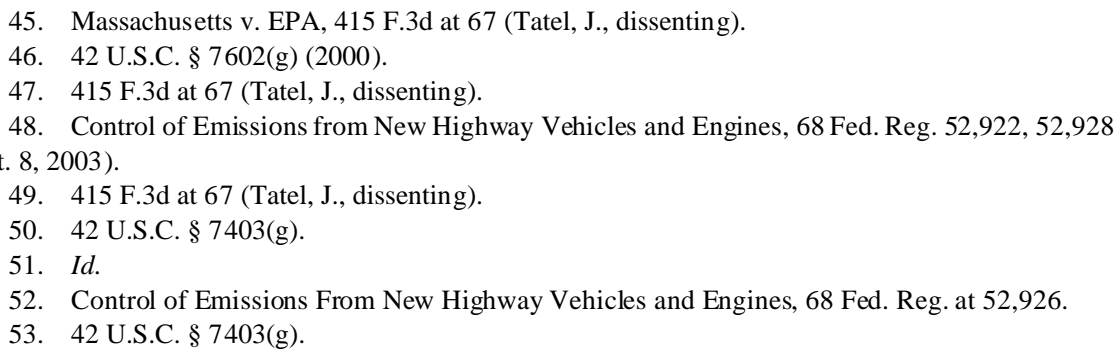


[f]aced with such language ... would normally end the analysis here and conclude that [greenhouse gases] are "air pollutants," since "we "must presume that a legislature says in a statute what it means and means in a statute what it says .... When the words of a statute are unambiguous ... this first canon is also the last: judicial inquiry is complete.", 54

Judge Tatel added that this analysis is "what courts typically call Chevron step one. $" 55$

Judge Tatel is correct that a court must follow the clear and unambiguous language in a federal statute, because under Chevron" "[i]f the intent of Congress is clear [as to whether a federal statute addresses the precise question at issue in a case], that is the end of the matter; for the court, as well as the agency [which administers the statute], must give effect to the unambiguously expressed intent of Congress." 57 Under this principle, which often is referred to as Chevron step one, a court may determine if a statute is clear and unambiguous on the basis of both its plain language and the "traditional tools of statutory construction," ${ }^{58}$ including evidence of legislative intent such as that found in a statute's legislative history. ${ }^{59}$ If the court finds that Congress's intent as to a statute's application to a precise question is clear and unambiguous, the court must follow this clear and unambiguous Congressional intent and is not permitted to follow a differing interpretation of the statute by the administrative agency charged with enforcement of the statute. However, if the court finds that the statute is silent or ambiguous with respect to the specific issue, the court, under an approach referred to as Chevron step two, is required to follow the administrative agency's interpretation of the statute if that interpretation is expressed in a formal agency rule or formal adjudication decision ${ }^{60}$ and is a reasonable interpretation

54. 415 F.3d at 67-68 (Tatel, J., dissenting) (quoting Conn. Nat'l Bank v. Germain, 503 U.S. 249, 253-54 (1992)) (omissions in original).

55. Judge Tatel had cited Chevron earlier in his dissent for the proposition that "if a court, employing traditional tools of statutory construction, ascertains that Congress had an intention on the precise question at issue, that intention is the law and must be given effect." 415 F.3d at 67 (citing Chevron U.S.A., Inc. v. Natural Res. Def. Council, 467 U.S. 837, 843 n.9 (1984)).

56. 467 U.S. 837 (1984).

57. Chevron, 467 U.S. at 842 .

58. Id. at 843 n.9.

59. Engine Mfrs. Ass'n v. EPA, 88 F.3d 1075, 1088 (D.C. Cir. 1996) ('Thus if apparently plain language compels an 'odd result,' the court may refer to evidence of legislative intent other than the text itself, such as the legislative history. Public Citizen v. Department of Justice, 491 U.S. 440, 454 (1989) (quoting Green v. Bock Laundry Mach. Co., 490 U.S. 504, 509 (1989)).”).

60. Christensen v. Harris County, 529 U.S. 576, 587 (2000). 
of the silent or ambiguous statute, taking into account the purposes and structure of the statute. ${ }^{61}$

Judge Tatel correctly found under Chevron step one that carbon dioxide and other greenhouse gases are "air pollutants" under section 302(g) and 202(a)(1) of the Clean Air Act, because the "exceedingly broad language [of section 302(g)'s definition of "air pollutant"] plainly covers [greenhouse gases] emitted from motor vehicles: they are 'physical [and] chemical . . . substances or matter . . . emitted into . . the ambient air." "62 As Judge Tatel added later in his dissent, "section 103(g) [of the Clean Air Act] explicitly calls [carbon dioxide] an 'air pollutant," ${ }^{63}$ and "Congress [in the Clean Air Act] gave EPA broad authority to regulate all harmful pollutants, as section 202(a)(1)'s text makes clear. Congress did so intentionally, deeming it 'not appropriate to exempt certain pollutants' from the Act's 'comprehensive protections." ${ }^{64}$ Consequently, because Congress has clearly expressed its intent, in the plain language and legislative history of the Clean Air Act, that carbon dioxide and other greenhouse gases are "air pollutants" for purposes of section 202(a)(1), a court is required by the Chevron step one doctrine to follow Congress's clearly expressed intent and to disregard an administrative agency's differing interpretation of the statute.

Nevertheless, Judge Tatel explained that the EPA was " $[\mathrm{u}]$ nswayed by what it calls "narrow semantic analyses" ${ }^{65}$ and:

claims that a "more holistic analysis ... [of] the text, structure, and history of the CAA as a whole, as well as the context provided by other legislation that is specific to climate change," justifies its conclusion that it cannot regulate [greenhouse gases] like [carbon dioxide] for their effects on climate change. ${ }^{66}$

Judge Tatel responded to this argument by stating that for the EPA " $[\mathrm{t}] \mathrm{o}$ disregard the Act's plain text in this way, EPA needs an 'extraordinarily convincing justification," ${ }^{67}$ because for the EPA "to avoid a literal interpretation at Chevron step one, it must show either that, as a matter of historical fact, Congress did not mean what it appears to have said, or that, as

61. Babbitt v. Sweet Home Chapter of Communities for a Great Or., 515 U.S. 687 (1995).

62. Massachusetts v. EPA, 415 F.3d 50, 67 (D.C. Cir. 2005) (Tatel, J., dissenting) (quoting Conn. Nat'1 Bank v. Germain, 503 U.S. 249, 253-54 (1992)) (omissions in original).

63. Massachusetts v. EPA, 415 F.3d at 72.

64. Id. at 71 .

65. Id. at 68 (quoting Respondent's Brief at 55 (No. 03-1361)).

66. Id. (quoting Respondent's Brief at 25-26 (No. 03-1361)).

67. 415 F.3d at 68 (Tatel, J., dissenting) (quoting Appalachian Power Co. v. EPA, 249 F.3d 1032, 1041 (D.C. Cir. 2001)). 
a matter of logic and statutory structure, it almost surely could not have meant it." 68

Judge Tatel's source for the "extraordinarily convincing justification" standard is Appalachian Power Co. v. EPA, ${ }^{69}$ a decision by the United States Court of Appeals for the District of Columbia. In a passage that was followed by a reference to Chevron step one,$^{70}$ the court in Appalachian Power Co. stated that "[r]eading a statute contrary to its seemingly clear meaning is permissible 'if the literal application of a statute will produce a result demonstrably at odds with the intentions of its drafters, ${ }^{, "}{ }^{71}$ but that a court "will not, however, invoke this rule to ratify an interpretation that abrogates the enacted statutory text absent an extraordinarily convincing justification." ${ }^{, 72}$ The "demonstrably at odds" phrase in this quotation is from the Supreme Court's 1989 decision in United States v. Ron Pair Enterprises, Inc. ${ }^{73}$ which held, without citing or discussing Chevron, that "[t]he plain meaning of legislation should be conclusive, except in the "rare cases [in which] the literal application of a statute will produce a result demonstrably at odds with the intention of its drafters." ${ }^{74}$

Judge Tatel discussed four justifications that the EPA advocated for "abandoning the [Clean Air] Act's text," 75 but he found that "[n]one of these reasons provides a convincing justification-let alone an "extraordinarily convincing' one-for EPA's counter-textual position."76 Consequently, he concluded that these four justifications are insufficient grounds for disregarding his initial conclusion under Chevron step one, and he therefore found that "[greenhouse gases] plainly fall within the meaning of "air

68. 415 F.3d at 68 (Tatel, J. dissenting) (quoting Engine Mfrs. Ass'n v. EPA, 88 F.3d 1075, 1089 (D.C. Cir. 1996)). The court in Engine Manufacturers Ass' $n$ did not cite any Supreme Court decisions or any other court decisions in support of this principle. Prior to the statement of this principle, the court in Engine Manufacturers Ass' $n$ stated that " $[\mathrm{t}] \mathrm{he}$ court's role is not to 'correct' the text so that it better serves the statute's purposes, for it is the function of the political branches not only to define the goals but also to choose the means for reaching them." 88 F.3d at 1089 (citations omitted).

69. 249 F.3d 1032 (D.C. Cir. 2001).

70. Id. at 1041 .

71. Id. (quoting Mova Pharm. Corp. v. Shalala, 140 F.3d 1060, 1068 (D.C. Cir. 1998)).

72. Id. (" $[\mathrm{t}] \mathrm{h}$ court's role is not to 'correct' the text so that it better serves the statute's purposes) (quoting Engine Mfrs. Ass'n, 88 F.3d 1075 at 1089); see supra note 68.

73. 489 U.S. 235 (1989).

74. Id. at 242 (quoting Griffin v. Oceanic Contractors, Inc., 458 U.S. 564, 571 (1982)).

75. 415 F.3d at 68 (Tatel, J., dissenting).

76. Id. 
pollutant' in section 302(g) and therefore in section 202(a)(1) [of the Clean Air Act]." 77

The EPA's first justification for not defining "air pollutants" under the Clean Air Act to include greenhouse gases was that "since the 1965, 1970, and 1977 Congresses [that enacted amendments to the Clean Air Act] were not specifically concerned with global warming, the Act cannot apply to [greenhouse gases]." 78 Although Judge Tatel conceded that the legislative history of the 1965, 1970 and 1977 Clean Air Acts contain only "a few stray references to human-forced climate change," 79 he noted that "in those years the scientific understanding of the issue was nascent at best." ${ }^{\text {"I0 }}$ Judge Tatel concluded that "EPA errs in suggesting that because Congress may not have precisely foreseen global warming, the [Clean Air] Act provides no authorization for [greenhouse gas] regulation," ${ }^{11}$ pointing out that the definition of "air pollutants" under section 302(g) "enables the Act to apply to new air pollution problems as well as existing ones," ${ }^{\circ 2}$ and that Congress in 1970, in adding section 302(h) ${ }^{83}$ to the Clean Air Act, "expressly instructed EPA to be on the lookout for climate-related problems in evaluating risks to 'welfare." ", 84

The EPA's second justification for not applying section 202(a)(1) to greenhouse gases was that "for practical and policy reasons global warming should be dealt with through specifically tailored statutes . . . [because] a statute aimed solely at global warming would deal with the problem more effectively than one aimed generally at air pollution." ${ }^{85}$ Judge Tatel rejected this second reason on the grounds that the EPA "may not 'avoid the Congressional intent clearly expressed in the [statutory] text simply by asserting that its preferred approach would be better policy." " 86 The EPA tried to strengthen this second reason "by claiming that because the 1977 and 1990 Congresses enacted provisions [amending the Clean Air Act] specific to

\footnotetext{
77. Id. at 73 .

78. Id. at 68 .

79. Id. (citing 111 Cong. Rec. 25061 (Sept. 24, 1965) (statement of Rep. Helstoski); 116 Cong. Rec. 32914 (Sept. 21, 1970) (report introduced in the record by Sen. Boggs)).

80. 415 F.3d at 68.

81. Id.

82. Id. (the Supreme Court has stated that "[t]he fact that a statute can be applied in situations not expressly anticipated by Congress does not demonstrate ambiguity. It demonstrates breadth." (quoting PGA Tour, Inc. v. Martin, 532 U.S. 661, 689 (2001)).

83. 42 U.S.C. $\$ 7602(\mathrm{~h})(2000)$; see supra text accompanying notes $31-32$.

84. 415 F.3d at 69.

85. Id.

86. Id. (quoting Engine Mfrs. Ass'n v. EPA, 88 F.3d 1075, 1089 (D.C. Cir. 1996)).
} 
another global pollution problem-depletion of stratospheric ozone-we must infer that the Act's general provisions do not cover such global problems." ${ }^{\text {87 }}$ Judge Tatel noted that Congress in 1977 enacted legislation ${ }^{88}$ that made clear that "nothing in this [ozone-specific] part shall be construed to alter or affect the authority of the [EPA] Administrator ... under any other provision of this Act," ${ }^{89}$ and found "nothing in the 1990 Congress's enactment of other provisions specific to stratospheric ozone, see 42 U.S.C. $\S \S 7671$ to 7671 q, indicating it thought the EPA lacked authority under general provisions like section 202 to regulate emissions contributing to global pollution." 90

Judge Tatel rejected the EPA's unworkability argument in support of its second justification, because the "EPA acknowledges . . . [that] regulating [carbon dioxide] emissions from automobiles is perfectly feasible" and practical through improved fuel economy. ${ }^{91}$ This argument was premised upon a contention that state regulation of carbon dioxide emissions, under state implementation plans adopted under section $110^{92}$ of the Clean Air Act, would be "unworkable." As discussed in Part IV of this Article, ${ }^{93}$ states would be required to regulate emissions of carbon dioxide under section 110 state implementation plans if carbon dioxide was listed as a criteria pollutant under section $108^{94}$ of the Clean Air Act and the EPA established national ambient air quality standards for carbon dioxide under section 109 (b). ${ }^{95}$ The EPA asserted that states would be unable to achieve national ambient air quality standards for carbon dioxide under state implementation plans because carbon dioxide "disperses relatively evenly throughout the lower atmosphere,

87. 415 F.3d at 69 .

88. Clean Air Act of 1977, Pub. L. No. 95-95, § 158, 91 Stat. 685, 730 (1977).

89. Id.

90. 415 F.3d at 69. Judge Tatel also noted that a House Committee had stated in 1977 that it believed that prior to the enactment in 1977 of Clean Air Act provisions aimed specifically at ozone depletion, the EPA already had authority under an existing general provision of the Clean Air Act to regulate emissions of pollutants to protect stratospheric ozone, H.R. REP. No. 95-294, at 102 (1977), and that Congress hadenacted provisions, 42 U.S.C. $\$ \S 7651$ to 7651 o, to deal specifically with certain regional pollutants to control acid rain even though the EPA already had authority to regulate such pollutants under general Clean Air Act provisions. 415 F.3d at 69.

91. 415 F.3d at 70.

92. 42 U.S.C. $\$ 7410$ (2000).

93. Infra notes $288-96$ and accompanying text.

94. 42 U.S.C. $\$ 7408$

95. Id. at $\$ 7409$ (b). Part IV of this article, infra notes 288-98 and accompanying text, discusses regulations that a state might include in a state implementation plan adopted under section 110 of the Clean Air Act, to control emissions of carbon dioxide from in-use on-road vehicles, if carbon dioxide was listed as a criteria pollutant under section 108 of the Act and the EPA established national ambient air quality standards for carbon dioxide under section 109 of the Act. 
[so] states would have only minimal control over their atmospheric [carbon dioxide] concentrations and thus over whether they meet the [carbon dioxide national ambient air quality standards]. ${ }^{" 96}$ This unworkability argument was premised upon a contention that because regulation of carbon dioxide emissions would be unworkable under section 110 state implementation plans, the EPA is not authorized to regulate greenhouse gas emissions under section 202(a)(1) or any of the other general provisions of the Clean Air Act. ${ }^{97}$ Judge Tatel concluded, however, that the unworkability of section 110 state implementation plans "would justify at most an exception limited to the particular unworkable provision" under the "absurd-results canon." 98

As its third justification for not considering greenhouse gases to be "air pollutants" subject to regulation under section 202(a)(1) of the Clean Air Act, the EPA relied upon FDA v. Brown \& Williamson Tobacco Corp.,${ }^{99}$ which the EPA argued supported the proposition "that Congress's passage of legislation calling for study of climate change, along with Congress's failure to pass any provisions [for the Clean Air Act] tailored solely to regulating [greenhouse gases], demonstrates that the [Clean Air Act] cannot apply to [greenhouse gases]." ${ }^{100}$ The EPA's argument in support of this third reason relied upon the following specific congressional action and inaction:

(1) ... all direct references to [carbon dioxide] or global warming in the 1990 [Clean Air Act] amendments appear in nonregulatory provisions; (2) . . other congressional acts such as the 1978 National Climate Program Act, the 1987 Global Climate Protection Act, the 1990 Global Change Research Act, and the 1992 Energy Policy Act, as well as several appropriations riders, touch specifically on the issue of global warming, typically by instructing agencies to study the issue; and (3) . . . Congress has considered and rejected many bills specifically tailored to [greenhouse gases] emissions regulation since at least $1990 .{ }^{101}$

96. Massachusetts v. EPA, 415 F.3d at 70 (Tatel, J., dissenting).

97. Id.

98. Id.

99. 529 U.S. 120 (2000).

100. Massachusetts v. EPA, 415 F.3d at 68 (Tatel, J., dissenting).

101. Id. at 70. In this part of his opinion, Judge Tatel did not explicitly discuss, as did the EPA Administrator in his decision, section 602(e) of the Clean Air Act, which directs the EPA to determine the global warming potential of substances that deplete stratospheric ozone. The EPA Administrator stressed in his decision that this provision did not authorize the imposition of man datory requirements and expressly precludes its use for regulatory purposes. Control of Emissions from New Highway Vehicles and Engines, 68 Fed. Reg. 52,922, 52,926 (Sept. 8, 2003). The EPA Administrator failed to note, however, that section $602(\mathrm{~g})$, which specifically states that " $[\mathrm{t}$ ]he preceding sentence [directing the Administrator to publish the global warming potential of listed substances] shall not be construed to be the basis of any additional regulation under [the Clean Air Act]," does not prohibit the EPA Administrator from regulating emissions of greenhouse gases under other sections of the Clean Air Act. 
Although Judge Tatel noted that "[o]ne might well wonder what all this has to do with whether [greenhouse gases] are 'air pollutants' within the meaning of [Clean Air Act] section 302(g), ${ }^{102}$ he noted that the EPA relied "almost exclusively" on Brown \& Williamson Tobacco Corp. in claiming "that together these facts indicate that the [Clean Air Act's] general provisions do not cover [greenhouse gases] . . . and that, as in Brown \& Williamson, the 'extraordinary' political and economic significance of the regulation requested casts doubts on the agency's authority to undertake it."103

In Brown \& Williamson Tobacco Corp., the Supreme Court decided the issue of whether the Food and Drug Administration (FDA) has authority, under the Food, Drug and Cosmetic Act (FDCA), to regulate tobacco products. The Supreme Court held in that case that the FDA did not have such authority, even though the "broad language" of the FDCA "suggested that it did," 104 because federal statutes enacted subsequent to the FDCA (which mandated specified warnings on tobacco products and regulated the advertising of tobacco products) embody a specific policy of permitting tobacco products to remain on sale. The Supreme Court noted that if the FDA was held to have authority to regulate tobacco products under the FDCA, the FDA would have to ban tobacco products from sale entirely due to their health risks despite the fact that subsequently enacted federal legislation indicated that Congress intended tobacco products to remain for sale on the market. Judge Tatel also noted that the Supreme Court in Brown \& Williamson Tobacco Corp. emphasized numerous times that the FDA repeatedly had claimed to have no authority to regulate tobacco products, and that the Supreme Court stated that "Congress's tobacco-specific statutes had effectively ratified the FDA's long-held position."

Judge Tatel found that "EPA's reliance on Brown \& Williamson is misplaced"106 for a number of reasons. First, he noted that the EPA's jurisdiction over greenhouse gas emissions under section 202(a)(1) "would [not] be as significant as FDA jurisdiction over tobacco" because the EPA "already extensively regulates the energy and transportation industries" under the Clean Air Act,

102. 415 F.3d at 70 .

103. Id.

104. $I d$.

105. Id. at 71 (quoting FDA v. Brown \& Williamson Tobacco Corp., 529 U.S. 120, 144 (2000)). 106. Massachusetts v. EPA, 415 F.3d at 71. 
whereas the FDA had no prior authority over the tobacco industry. Moreover, EPA jurisdiction would lead only to regulation of [greenhouse gases]-with, in the case of section 202, regulation taking effect only after "such period as the Administrator finds necessary" for development of technology, "giving appropriate consideration to the cost of compliance.” 42 U.S.C. $\$ 7521(\mathrm{a})(2)$. By contrast, FDA jurisdiction over tobacco would have triggered a total product ban. ${ }^{107}$

Judge Tatel also concluded that, unlike Brown \& Williamson Tobacco Corp., the present case involving regulation of greenhouse gas emissions under section 202 of the Clean Air Act "is not an 'extraordinary case' where 'common sense' . . calls into question whether Congress has delegated EPA authority to regulate [greenhouse gases]." ${ }^{108}$ He stressed that "Congress gave EPA broad authority to regulate all harmful pollutants, as section 202(a)(1)'s text makes clear... [and] did so intentionally, deeming it 'not appropriate to exempt certain pollutants' from the Act's 'comprehensive protections.",109

Judge Tatel also concluded that "no subsequent statutory indicia comparable to those relied on by the Court in Brown \& Williamson justify a different conclusion [and] [p]erhaps most significantly, no conflict exists between EPA's section 202(a)(1) authority to regulate [greenhouse gases] and subsequent global warming legislation." ${ }^{110}$ He explained that EPA regulation of greenhouse gases "would be fully compatible with statutes proposing additional research and other nonregulatory approaches to climate change," "[w]hereas an FDA ban on tobacco would have directly conflicted with congressional intent that tobacco remain on the market." "111 Specifically, he found that three provisions ${ }^{112}$ of the Clean Air Act enacted in 1990 which refer either to carbon dioxide or to global warming do not explicitly provide nor suggest that the EPA lacks authority to regulate carbon dioxide under other parts of the Act and that "[o]ther climate related acts[] ${ }^{113}$ similarly demonstrating congressional intent that global climate issues receive study

107. Id.

108. Id. (quoting Brown \& Williamson Tobacco Corp., 529 U.S. at 144).

109. Id. (quoting H.R. ReP. No. 95-294, at $42-43$ (1977)).

110. 415 F.3d at 71 .

111. $I d$.

112. 42 U.S.C. $\$ 7403(\mathrm{~g}) ; 42$ U.S.C. $§ 7671 \mathrm{a}(\mathrm{e})$; Clean Air Act of 1990, Pub. L. No. 101-549, § 821, 104 Stat. 2399, 2699 (1990).

113. National Climate Program Act of 1978,Pub.L. No. 95-367, 92 Stat. 601 (1978); Global Climate Protection Act of 1987, Pub. L. No. 100-204, §§ 1101-06, 101 Stat. 1331, 1407-09 (1987); Global Change Research Act of 1990, Pub. L. No. 101-606, 104 Stat. 3096 (1990); Energy Policy Act of 1992, Pub. L. No. 102-486, 106 Stat. 2776 (1992). 
and attention are likewise perfectly compatible with [greenhouse gases] regulation." 114

Judge Tatel also noted that the EPA had not claimed that it lacked authority under the Clean Air Act to regulate greenhouse gas emissions at the time that these subsequent global warming related statutes were enacted, ${ }^{115}$ whereas in Brown \& Williamson Tobacco Corp. "subsequent tobacco legislation "effectively ratified the FDA's previous position" "116 that it did not have authority to regulate tobacco products. In his reasoning in support of this final point for rejecting the EPA's third justification, Judge Tatel discounted the failure of later Congresses to enact "bills specifically tailored to regulating global warming" on the grounds that such inaction "hardly provides a basis for inferring that earlier Congresses meant to exclude climate-endangering pollutants from the coverage of the [Clean Air Act's] general provisions." 117

The EPA's fourth justification for not considering carbon dioxide to be an "air pollutant" under section 202(a)(1) of the Clean Air Act was that Congress could not have had such an intent "since EPA regulation [under section 202(a)(1) of the Clean Air Act] of [carbon dioxide] emissions from automobiles would overlap with Department of Transportation (DOT) authority over fuel economy standards under [the 1975 Energy Policy and Conservation Act (EPCA) $)^{118}$." ${ }^{119}$ The DOT has authority under EPCA to establish average fuel economy standards for certain classes of motor vehicles. ${ }^{120}$ This EPA argument is premised upon the EPA's contention that "the only practical way to regulate [carbon dioxide] emissions from motor vehicles is to require increased fuel economy, since [carbon dioxide] is a byproduct of fuel combustion and "no technology currently exists or is under

114. 415 F.3d at 71.

115. Judge Tatel noted that the EPA took the position that it had authority to regulate greenhouse gas emissions under section 202(a)(1) of the Clean Air Act at the time of enactment of two appropriation riders, Departments of Veterans Affairs and Housing and Urban Development, and Independent Agencies Appropriations Act of 1999, Pub. L. No. 105-276, 112 Stat. 2461, 2496 (1998) (barring use of funds for implementation of the Kyoto Protocol on global warming). 415 F.3d at 72.

116. 415 F.3d at 72 (quoting FDA v. Brown \& Williamson Tobacco Corp., 529 U.S. 120, 156 (2000)).

117. 415 F.3d at 72. He stressed that "[n]ot only is "subsequent legislative history ... a hazardous basis for inferring the intent of an earlier Congress,' but it 'is a particularly dangerous ground . . . when it concerns, as it does here ... proposals that do not become law." Id. (quoting Pension Benefit Guar. Corp. v. LTV Corp., 496 U.S. 633, 650 (1990)) (citation omitted). He added: "[I]ndeed, in interpreting the scope of the FDA's authority, the Brown \& Williamson Court itself expressly declined to rely on failed legislation." 415 F.3d at 72 (citing 529 U.S. at 155).

118. Energy Policy and Conservation Act, Pub. L. No. 94-163, § 502, 89 Stat. 871, $902-07$ (1975).

119. 415 F.3d at 68 (Tatel, J., dissenting).

120. This DOT authority under the EPCA is discussed infra notes 253-57 and accompanying text. 
development that can capture and destroy or reduce [carbon dioxide] emissions from motor vehicle tailpipes." ${ }^{121}$

Judge Tatel rejected this fourth argument by the EPA on the grounds that "the two regulatory regimes - one [(EPCA)] targeted at fuel conservation and the other [(Clean Air Act $)]$ at pollution prevention-are overlapping, not incompatible." ${ }^{122} \mathrm{He}$ suggested ${ }^{123}$ that if the EPA's only practical option at the present time for regulating carbon dioxide emissions from motor vehicles is setting standards for fuel economy, rather than standards for capturing tailpipe carbon dioxide emissions, then under section 202(a)(2) $)^{124}$ of the Clean Air Act, such section 202(a)(1) fuel economy standards shall take effect only "after such period as the Administrator finds necessary to permit the development and application of the requisite technology." However, although the EPA argued that EPA fuel economy standards established under section 202(a)(1) either would abrogate DOT fuel economy standards under the EPCA (if EPA standards were more stringent than DOT standards) or would be meaningless (if EPA standards were less stringent than DOT standards), Judge Tatel still concluded that the two statutes were overlapping and that therefore "there is no reason to assume that Congress exempted [carbon dioxide] from the meaning of 'air pollutant' within the [Clean Air Act]." 125 Judge Tatel concluded the part of his opinion rejecting the EPA's fourth justification by stating that " $[\mathrm{w}]$ here two 'statutes are capable of co-existence, it becomes the duty of this court' to regard each as effective-at least absent clear congressional intent to the contrary;" ${ }^{26}$ and that in both the EPCA and the Clean Air Act "Congress acknowledged, and indeed accepted, the possibility of regulatory overlap." 127

121. 415 F.3d at 72 (Tatel, J., dissenting) (quoting Control of Emissions from New Highway Vehicles and Engines, 68 Fed. Reg. 52,922, 52,929 (Sept. 8, 2003)).

122. 415 F.3d at 72 .

123. $I d$.

124. 42 U.S.C. $\$ 7521(\mathrm{a})(2)(2000)$.

125. 415 F.3d at 72.

126. Id. (quoting FTC v. Ken Roberts Co., 276 F.3d 583, 593 (D.C. Cir. 2001)).

127. 415 F.3d at 73. Judge Tatel continued by pointing out that the EPCA:

current[ly] . . . recognize[s] the relevance of "the effect of other motor vehicle standards of the Government on fuel economy," 49 U.S.C. § 32902(f); see also EPCA, Pub. L. No. 94-163, § 502(e), 89 Stat. at 905, but in passing the 1977 [Clean Air Act] amendments Congress emphasized that EPA regulation under the [Clean Air Act] should go forward even when it overlaps with responsibilities given to other agencies under other acts, see H.R. Rep. No. 95-294, at 42-43 (explaining that Congress was amending section 302(g) to broaden the meaning of "air pollutants" and make clear that EPA has authority even over pollutants already regulated by another agency). 415 F.3d at 73 . 
Judge Tatel then noted that the 1977 House Report on the 1977 Clean Air Act amendments "explained .. . [that] 'the Clean Air Act is the comprehensive vehicle for protection of the Nation's health from air pollution. In the committee's view, it is not appropriate to exempt certain pollutants or certain sources from the comprehensive protections afforded by the Clean Air Act"" 128 and concluded that "[greenhouse gases] plainly fall within the meaning of 'air pollutant' in section 302(g) and therefore in section 202(a)(1) [of the Clean Air Act]." 129

Judge Randolph "assume[d] arguendo that EPA has statutory authority [under section 202(a)(1) of the Clean Air Act] to regulate greenhouse gases [emissions] from new motor vehicles," 130 but held that "the EPA Administrator properly exercised his discretion under [section] 202(a)(1) in denying the petition for rulemaking [that would regulate greenhouse gas emissions from new motor vehicles]."131

Judge Sentelle, although dissenting in part to the majority's holding that petitioners had standing to sue, ${ }^{132}$ joined Judge Randolph's decision to deny the four petitions challenging the EPA's final action in refusing to grant the petition for rulemaking. Judge Sentelle issued no opinion in support of his decision to concur in this judgment.

Judge Tatel, in dissent, argued that none of the policy reasons set forth by the EPA in support of its decision to deny the petition for rulemaking, relate to the statutory standard under section 202(a)(1), ${ }^{133}$ that requires the EPA Administrator to prescribe a standard under that section applicable to the emission of an air pollutant from new motor vehicles "which in his judgment cause, or contribute to, air pollution which may reasonably be anticipated to endanger public health or welfare." 134

Judge Randolph, however, concluded that the EPA Administrator properly exercised his discretion under section 202(a)(1) of the Clean Air Act in deciding not to set standards for carbon dioxide emissions for new motor vehicles. Relying upon Ethyl Corp. v. EPA ${ }^{135}$ he stated that the EPA Administrator has considerable discretion under section 202(a)(1) in making a threshold judgment about whether to regulate and that the EPA

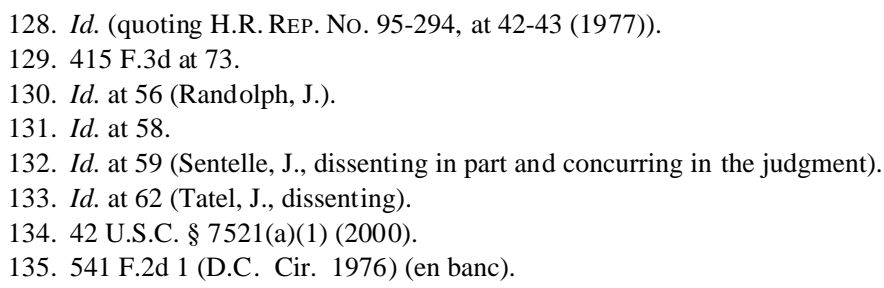


Administrator can exercise this discretion on the basis both of his assessment of scientific evidence and policy judgments: "the sort of policy judgments Congress makes when it decides whether to enact legislation regulating a particular area." 136 Judge Randolph found that the EPA's grounds for denying the petition for rulemaking under section 202(a)(1) "is entirely consistent" with the Ethyl Corp. decision," because EPA denied the petition for rulemaking on the basis of both "scientific uncertainty about the causal effects of greenhouse gases on the future climate of the earth" ${ }^{137}$ and "many 'policy' considerations that, in his judgment, warranted regulatory forbearance at this time." 138

One of these policy considerations noted by Judge Randolph was that new motor vehicles are only one of many sources of greenhouse gas emissions and that promulgation of standards under section 202(a)(1) to control greenhouse gas emissions from new motor vehicles would "result in an inefficient, piecemeal approach to the climate change issue." 139 Another policy reason he noted was "that unilateral regulation of U.S. motor vehicle emissions could weaken efforts to persuade developing countries to reduce the intensity of greenhouse gases thrown off by their economies." ${ }^{140}$ Judge Randolph also explained that "[o]ngoing research into scientific uncertainties and the Administration's programs to address climate change including voluntary emission reduction programs and initiatives with private entities to develop new technology also played a role in the Administrator's decision not to regulate." ${ }^{\prime 41}$ Judge Randolph noted that the EPA Administrator had rejected

136. 415 F.3d at 58 (quoting Ethyl Corp., 541 F.2d at 20, 26). As discussed infra notes 168-77 and accompanying text, Judge Tatel in his dissenting opinion argued that Ethyl Corp. limits the EPA's exercise of policy judgment under section 202(a)(1) of the Clean Air Act to a determination of endangerment to public health based on an assessment of risks, in relationship to other provisions of the Clean Air Act; and that the EPA "Administrator is [not] free to set policy on his own terms." 415 F.3d at 76 (quoting Ethyl Corp., 541 F.2d at 29).

137. 415 F.3d at 58. Judge Randolph explained that the EPA Administrator had based this finding of scientific uncertainty upon a report issued in 2001 by the National Research Council entitled Climate Change Science: An Analysis of Some of the Key Questions, which caused the EPA Administrator to conclude that it should forego rulemaking under section 202(a)(1) "until more is understood about the causes, extent and significance of climate change and the potential options for addressing it." Control of Emissions from New Highway Vehicles and Engines, 68 Fed. Reg. 52,922, 52,931 (Sept. 8, 2003).

138. 415 F.3d at 58 (citing Control of Emissions from New Highway Vehicles and Engines, 68 Fed. Reg. at 52,929). 52,931).

139. Id. (quoting Control of Emissions from New Highway Vehicles and Engines, 68 Fed. Reg. at

140. Id. (citing Control of Emissions from New Highway Vehicles and Engines, 68 Fed. Reg. at $52,931)$.

141. Judge Randolph referred to the EPA's reference to efforts to develop fuel cell and hybrid 
the two alternative ways offered by the petitioners to control carbon dioxide emissions from new motor vehicles-reduced gasoline consumption and improved tire performance-on the grounds that the DOT has established fuel efficiency standards that have prevented emissions of millions of metric tons of carbon dioxide and that the EPA probably does not have authority under section 202 of the Clean Air Act to regulate tire efficiency as an "emission" of an air pollutant. ${ }^{142}$ Finally, Judge Randolph noted that the EPA Administrator had indicated that the petitioners had not presented the EPA with any suggestions as to how emissions of the other greenhouse gases (methane, nitrous oxide, and hydrofluorocarbons) from motor vehicles might be reduced. ${ }^{143}$

Judge Randolph then stated that petitioners had not accurately characterized the EPA's refusal to regulate greenhouse gas emissions from new motor vehicles as a decision that "rested entirely on scientific uncertainty, or that EPA's decision represented an 'open-ended invocation of scientific uncertainty to justify refusing to regulate." 144 Stating that "[a] determination of endangerment to public health is necessarily a question of policy that is to be based on an assessment of risks and that should not be bound by either the procedural or the substantive rigor proper for questions of fact," 145 and that "a reviewing court 'will uphold agency conclusions based on policy judgments' when an agency must resolve issues on the 'frontiers of scientific knowledge," "146 Judge Randolph held that the EPA Administrator properly exercised his discretion under section 202(a)(1) of the Clean Air Act in denying the petition seeking to have the EPA set standards for greenhouse gas emissions from new motor vehicles. ${ }^{147}$

Judge Tatel, in dissent, argued that "none of these policy" reasons relied upon by the EPA Administrator to deny the petition for rulemaking "relates to the statutory standard [in section 202(a)(1) of the Clean Air Act]—cause, or contribute to, air pollution which may reasonably be anticipated to endanger public health or welfare," and asserted that "the Clean Air Act gives the Administrator no discretion to withhold regulation for such reasons." 148

vehicles and hydrogen as a primary fuel for automobiles and trucks. Id. (citing Control of Emissions from New Highway Vehicles and Engines, 68 Fed. Reg. at 52,931).

142. Id.

143. 415 F.3d at 58.

144. Id. (citation omitted).

145. Id. (quoting Ethyl Corp. v EPA, 541 F.2d 1, 24 (D.C. Cir. 1976) (en banc)).

146. Id. (quoting Envtl. Def. Fund v. EPA, 598 F.2d 62, 82 (D.C. Cir. 1978)).

147. 415 F.3d at 58.

148. Id. at 62 . 
He added later in his opinion that greenhouse gas emissions from new motor vehicles can be regulated by the EPA under section 202(a)(1) even though motor vehicles are not the only source of greenhouse gas emissions. ${ }^{149}$

Judge Tatel noted that the EPA Administrator's denial of the petition for rulemaking under section 202(a)(1) of the Clean Air Act was subject to judicial review under the arbitrary and capricious standard, ${ }^{150}$ which requires a reviewing court to determine if "the agency's decision making was reasoned, ... [and whether] the agency ... [made] plain errors of law." mentioned by Judge Tatel, the Supreme Court has stated that in order for a reviewing court to determine that an agency's decision was not "arbitrary, capricious, an abuse of discretion, or otherwise not in accordance with law" under section 706(2)(A) of the Administrative Procedure Act, ${ }^{152}$ "the court must consider whether the decision was based on the relevant factors and whether there has been a clear error of judgment." 153

Judge Tatel argued that he believed that the EPA Administrator had failed to satisfy this arbitrary and capricious standard ${ }^{154}$ adding that he found "it difficult even to grasp the basis for EPA's action." ${ }^{55}$ Judge Tatel found that the EPA Administrator, both in his commentary accompanying his denial of the petition for rulemaking and in his brief submitted to the court, argued that he has discretion under section 202(a)(1) either not to make any finding, affirmative or negative, as to whether carbon dioxide emissions endanger public health or welfare, or not to set emission standards under section 202(a)(1) even if he makes an affirmative endangerment finding. ${ }^{156}$ Judge

149. Id. at 80 (citing Ethyl Corp., 541 F.2d at 29-31).

150. Id. at 73. Although Judge Tatel did not do so, Judge Randolph had noted that the court had jurisdiction under section 307(b) of the Clean Air Act to review the EPA Administrator's denial of the petition for rulemaking at issue in the case. Id. at 53-54. Judge Tatel did note that actions of the EPA Administrator under the Clean Air Act that are subject to judicial review are reviewed under the arbitrary and capricious standard under section 307(b)(9) which authorizes a court to reverse any action of the EPA Administrator to which section 307(b) applies that the court finds is "arbitrary, capricious, an abuse of discretion, or otherwise not in accordance with law." Id. at 73.

151. 415 F.3d at 73 (quoting Am. Horse Prot. Ass'n v. Lynn, 812 F.2d 1, 5 (D.C. Cir. 1987)) (internal quotation marks omitted).

152. 5 U.S.C. $\$ 706(2)(A)$. Identical language is used in section 307(d)(9)(A) of the Clean Air Act, the provision governing judicial review in the case reviewing the EPA Administrator's decision not to regulate carbon dioxide emissions from new motor vehicles under section 202(a)(1) of the Clean Air Act.

153. Citizens to Pres. Overton Park, Inc. v. Volpe, 401 U.S. 402, 416 (1971). "Although this inquiry into the facts is to be searching and careful, the ultimate standard of review is a narrow one. The court is not empowered to substitute its judgment for that of the agency." Id.

154. 415 F.3d at 73.

155. $I d$.

156. Id. at 73-74. 
Tatel also found that the EPA Administrator had relied upon a number of policy concerns in deciding that regulation of greenhouse gas emissions under section 202(a)(1) "is a bad idea" and that therefore he should exercise his discretion to withhold making an endangerment finding under section 202(a)(1). Such a finding would involve him making a judgment as to whether greenhouse gas emissions "cause, or contribute to, air pollution which may reasonably be anticipated to endanger public health or welfare."157

Judge Tatel stated that these policy concerns included that:

(1) "there continue to be important uncertainties in our understanding of the factors that may affect future climate change and how it should be addressed"; (2) petitioners identified no technologies for reducing [methane, nitrous oxides and hydrofluorocarbons] emissions, and technologies for reducing [carbon dioxide] emissions either overlap with DOT's authority or require further development; (3) regulation "would also result in an inefficient, piecemeal approach to addressing the climate change issue," as the "U.S. motor vehicle fleet is one of many sources of [greenhouse gases] emissions both here and abroad"; (4) "unilateral EPA regulation of motor vehicle [greenhouse gases] emissions could also weaken U.S. efforts to persuade key developing countries to reduce the [greenhouse gases] intensity of their economies"; and (5) "EPA disagrees with the regulatory approach urged by petitioners," instead preferring "a number of nonregulatory approaches to reducing [greenhouse gases] emissions" in line with "the President's global climate change policy" of "supporting vital global climate research and laying the groundwork for future action by investing in science, technology, and institutions." 158

Later in his dissent, ${ }^{159}$ Judge Tatel stated that the EPA Administrator had not explicitly explained how any of these scientific uncertainties and policy considerations relate or link to the statutory standard under section 202(a)(1) which requires him to determine if an air pollutant emitted from new motor vehicles or their engines causes or contributes to air pollution which reasonably may be anticipated to endanger public health or welfare. Judge Tatel argued that Congress has given the EPA Administrator only "limited discretion" under section 202(a)(1) of the Clean Air Act "to determine whether or not an air pollutant causes or contributes to pollution which may reasonably be anticipated to endanger public health or welfare," not "discretion to withhold regulation because [he] thinks such regulation bad policy." 160 Judge Tatel asserted that section 202(a)(1) gives the EPA Administrator "the discretion only to judge, within the bounds of substantial

157. Id. at 73 .

158. Id. at 74 (quoting Control of Emissions from New Highway Vehicles and Engines, 68Fed. Reg. 52,922, 52,929-33 (Sept. 8, 2003)).

159. 415 F.3d at 81 .

160. Id. at 74 . 
evidence," whether particular pollutants "cause, or contribute to, air pollution which may reasonably be anticipated to endanger public health or welfare." 161 Judge Tatel noted that the EPA Administrator may withhold such an endangerment judgment for emissions of a particular pollutant under section 202(a)(1) in several different situations: when there is conflicting credible evidence (with "some evidence indicating that [the pollutant] may reasonably be anticipated to endanger welfare and other evidence suggesting the opposite"), when "the facts are known but require no single conclusion as to whether a pollutant "may reasonably be anticipated to endanger public health or welfare'- such as in a case where there exists a small-to-moderate risk that a pollutant will cause a small-to-moderate amount of harm," and when "the Administrator concludes based on substantial evidence that more research is needed before he can judge whether [a particular pollutant] may reasonably be anticipated to endanger welfare." "162

But Judge Tatel stated that "section 202(a)(1) plainly limits the Administrator's discretion-his judgment— to determining whether the statutory standard for endangerment has been met. The Administrator has no discretion either to base that judgment on reasons unrelated to this standard or to withhold judgment for such reasons."163

Judge Tatel found that the EPA's claim to the contrary not only ignored the plain language of section 202(a)(1), but also was contrary to a number of previous decisions of the United States Court of Appeals for the District of Columbia interpreting other provisions of the Clean Air Act that require the EPA Administrator to make an endangerment finding in setting certain emission or regulatory standards for air pollutants. He first discussed Natural Resources Defense Council, Inc. v. EPA, ${ }^{164}$ which held that the EPA Administrator could not consider costs of compliance or technological feasibility in setting emission standards for hazardous air pollutants under a then-existing provision ${ }^{165}$ of the Clean Air Act that required the standards to be set "at the level which in his judgment provides an ample margin of safety to protect the public health." The court in that case held that under that provision the EPA Administrator had to establish an emission standard for hazardous air pollutants at a level that he determined provided "an ample

161. $I d$.

162. Id. at 75 .

163. Id.

164. 824 F.2d 1146 (D.C. Cir. 1987) (en banc).

165. 42 U.S.C. $\$ 7412$ (b)(1)(B)(1982). This provision was amended by the 1990 Clean Air Act amendments. Clean Air Act Amendments, Pub. L. No. 101-549, § 301, 104 Stat. 2399, 2531 (1990). 
margin of safety" to protect public health, without regard to the cost of complying with the standard and without regard to whether it was technologically feasible to comply with the standard. ${ }^{166}$ Judge Tatel asserted that the decision "makes clear that the Administrator may only exercise 'judgment' in evaluating whether the statutory standard has been met."167

Ethyl Corp. v. EPA, ${ }^{168}$ upon which Judge Randolph relied ${ }^{169}$ to uphold the EPA Administrator's denial of the petition for rulemaking under section 202(a)(1), was also relied upon by Judge Tatel in support of his belief that the EPA Administrator had not complied with his statutory duties under section 202(a)(1). The court in Ethyl Corp. upheld the EPA's decision to adopt regulations under section $211(\mathrm{c})(1)(\mathrm{A}){ }^{170}$ of the Clean Air Act to reduce the permissible amount of lead additives in gasoline. Section 211(c)(1)(A) provided at the time that the EPA Administrator "may" regulate fuel additives "if any emission products of such ... fuel additives will endanger the public health or welfare." After determining that lead in gasoline presented a "significant risk of harm to the public health," the EPA issued regulations under section 211(c)(1)(A) that required the amount of lead additives in gasoline to be reduced significantly. The regulated industry challenged the regulations on the ground that the EPA Administrator had to prove actual harm to public health from lead in gasoline, rather than a significant risk of harm. ${ }^{171}$ The court in Ethyl Corp. held that the EPA Administrator had acted properly under section 211(c)(1)(A) to regulate after a finding of a significant risk of harm to public health. Judge Randolph had interpreted the Ethyl Corp. decision as "not requir[ing] the Administrator to exercise his discretion solely on the basis of his assessment of scientific evidence" and that the EPA Administrator also can "take[] into account . . . the sort of policy judgments Congress makes when it decided whether to enact legislation regulating a particular area." 172 Judge Tatel, however, stated that the court in Ethyl Corp.:

held that the agency had discretion in determining what level of harm-or risk of harm-constitutes endangerment ... [and] that such determinations involve policy

166. 824 F.2d at 1164-65.

167. Massachusetts v. EPA, 415 F.3d at 75 (Tatel, J., dissenting).

168. 541 F.2d 1 (D.C. Cir. 1976) (en banc).

169. Massachusetts v. EPA, 415 F.3d at 57-58. Judge Randolph's interpretation of Ethyl Corp. is discussed supra notes $135-38$ and accompanying text.

170. 42 U.S.C. $\$ 1857 f-6 c(1)(A)$ (1976), currently codified as amended at 42 U.S.C. $\$ 7545$ (c)(1)(A) (2000).

171. Ethyl Corp. v. EPA, 541 F.2d 1, 12 (D.C. Cir. 1976) (en banc).

172. Massachusetts v. EPA, 415 F.3d at 58. 
issues, but — as Judge Randolph neglects to mention, ... - - those policy issues all related to whether the statutory standard had been met, i.e., to whether lead in gasoline endangered public health." 173

In support of this interpretation of Ethyl Corp., Judge Tatel quoted the following two statements in Ethyl Corp.: "a determination of endangerment to public health is necessarily a question of policy that is to be based on an assessment of risks and that should not be bound by either the procedural or the substantive rigor proper for questions of fact," 174 and "the statute accords the regulator flexibility to assess risks and make essentially legislative policy judgments." $175 \mathrm{He}$ added that "[I]ndeed, Ethyl makes quite clear that the Administrator's policy-based discretion is limited to the terms of the statute," ${ }^{176}$ and then quoted the following passage from Ethyl Corp.:

All this is not to say that Congress left the Administrator free to set policy on his own terms. To the contrary, the policy guidelines are largely set, both in the statutory term "will endanger" and in the relationship of that term to other sections of the Clean Air Act. These prescriptions direct the Administrator's actions. ${ }^{177}$

These statements from Ethyl Corp. quoted by Judge Tatel clearly support his interpretation of the Ethyl Corp. decision rather than Judge Randolph's interpretation.

Judge Tatel also relied upon Her Majesty the Queen in Right of Ontario v. $E P A,{ }^{178}$ for the principle that "for EPA to decline to make an endangerment finding, it must have a statutorily based reason for doing so." 179 In that case, the EPA Administrator had declined to make an endangerment finding with respect to acid rain under section $115(\mathrm{a})^{180}$ of the Clean Air Act, which provided that when the Administrator had "reason to believe that any air pollutant . . . may reasonably be anticipated to endanger public health or welfare in a foreign country ... the Administrator shall give formal notice

173. Id. at 75-76 (Tatel, J., dissenting) (citations omitted).

174. Id. at 76 (quoting Ethyl Corp., 541 F.2d at 24).

175. Id. (quoting Ethyl Corp., 541 F.2d at 26).

176. Id. at 76 .

177. 415 F.3d at 76 (quoting Ethyl Corp., 541 F.2d at 29). Judge Tatel then observed that in Brown \& Williamson Tobacco Corp. the Supreme Court had noted that the FDA's "judgment" about how best to achieve public health goals is "no substitute for the specific safety determinations required by the FDCA's various operative provisions." Id.

178. 912 F.2d 1525 (D.C. Cir. 1990).

179. 415 F.3d at 76.

180. 42 U.S.C. $§ 7415$ (a) (1982) 
thereof to the Governor of the state in which such omission s originate." Judge Tatel stated that the court in that case:

held that EPA acted reasonably in postponing a formal endangerment finding only because it gave a reasonable statutory basis for doing so[,] . . . [that] EPA still lacked information as to which states were causing the harmful acid rain, [and therefore] it would have been "pointless" for the agency to make an endangerment finding given the "specific [statutory] linkage between the endangerment finding and the remedial procedures," i.e., notifying offending states. ${ }^{181}$

Judge Tatel therefore concluded that:

[The] EPA may withhold an endangerment finding only if it needs more information to determine whether the statutory standard has been met [and] [s]imilarly, for EPA to find no endangerment (as Judge Randolph, going beyond the agency's own arguments, appears to claim happened here ...), it must ground that conclusion in the statutory standard and may not rely upon unrelated policy considerations. ${ }^{182}$

Judge Tatel also observed that section 202(a)(1) of the Clean Air Act is "precautionary," 183 allowing the EPA Administrator to set standards for the emissions of an air pollutant which reasonably may be anticipated to endanger public health or welfare, without the need for actual harm or endangerment to public health or welfare to be occurring. He noted that at the time Ethyl Corp. was decided, section 202(a)(1) and some other sections of the Clean Air Act required or authorized the EPA Administrator to take specified action upon a finding that emissions caused "air pollution which endangers the public health or welfare." 184 He noted, however, that after Ethyl Corp. held that the EPA Administrator was permitted by such statutory language to take "regulatory action to prevent harm, even if the regulator is less than certain that harm is otherwise inevitable," ${ }^{185}$ Congress in 1977 amended the Clean Air Act to follow this precautionary or preventative standard in the present version of section 202(a)(1) and other sections of the Clean Air Act. ${ }^{186}$

Judge Tatel concluded that the EPA Administrator had relied upon impermissible policy considerations in denying the petition for rulemaking under section 202(a)(1) of the Clean Air Act:

181. 415 F.3d at 76 (quoting Her Majesty the Queen in Right of Ont. v. EPA, 912 F.2d 1525, 1533 (D.C. Cir. 1990))

182. Id. at 76 .

183. $I d$.

184. 42 U.S.C. $§ 1857 f-1(a)(1)$ (1976).

185. Ethyl Corp. v. EPA, 541 F.2d 1, 25 (D.C. Cir. 1976) (en banc).

186. Massachusetts v. EPA, 415 F.3d at 77 (citing H.R. REP. No. 95-294, at 50, 51 (1977)). 
Given this framework, it is obvious that none of EPA's proffered policy reasons justifies its refusal to find that [greenhouse gases] emissions "contribute to air pollution which may reasonably be anticipated to endanger public health or welfare." Unlike in Her Majesty the Queen, EPA's proffered reasons for refusing to make an endangerment finding have no connection to the statutory standard. Instead, as in Natural Resources Defense Council (where we found EPA to have acted arbitrarily and capriciously), EPA has "ventured into a zone of impermissible action" by "simply substituting" freestanding policy concerns for the sort of evaluation required by the statute $\ldots{ }^{187}$

Judge Tatel then found that "EPA['s] claims that global warming still has many scientific uncertainties associated with it" seemed to be calling for proof or unequivocal evidence, "whereas section 202(a)(1) only . . calls for the Administrator to determine whether [greenhouse gases] "contribute to air pollution which may reasonably be anticipated to endanger' welfare." ${ }^{188} \mathrm{He}$ noted that:

[The] EPA never suggests that the uncertainties identified by the [National Research Council] report prevent it from determining that [greenhouse gases] "may reasonably be anticipated to endanger" welfare. In other words, just as EPA failed in Natural Resources Defense Council to explain its chosen emissions level in light of the statutory standard, so the agency has failed here to explain its refusal to find endangerment in light of the statutory standard. ${ }^{189}$

Judge Tatel then stated that, taking into account the National Research Council report as a whole, he:

doubt[ed] that EPA could credibly conclude that it needs more research to determine whether [greenhouse gases]-caused global warming "may reasonably be anticipated to endanger" welfare. Though not offering certainty, the report demonstrates that matters are well within the "frontiers of scientific knowledge" ... The report also indicates that the projected consequences of global warming are serious. ${ }^{190}$

Because Judge Tatel's decision clearly establishes that the EPA Administrator, in denying the petition for rulemaking under section 202(a)(1) of the Clean Air Act to regulate greenhouse gas emissions from new motor vehicles, relied upon policy considerations that are not statutorily permissible relevant factors under section 202(a)(1), the court should have found that the

187. 415 F.3d at 77 (citation omitted).

188. Id. at 77 .

189. $I d$.

190. Id. at 77-78 (citations omitted). 
Administrator's decision was arbitrary and capricious within the meaning of section 307(b)(9) ${ }^{191}$ of the Clean Air Act.

However, as noted by Judge Tatel, the EPA Administrator never clearly has made an endangerment finding under section 202(a)(1) on the basis of scientific risk assessment considerations, and the court therefore should have remanded the case to the EPA Administrator with an order for him to make a decision on the petition for rulemaking on the explicit basis of whether scientific risk assessment indicates that greenhouse gas emissions from new motor vehicles or their engines "cause, or contribute to, air pollution which may reasonably be anticipated to endanger public health or welfare." As noted by Judge Tatel at the end of his dissenting opinion, ${ }^{192}$ the EPA Administrator would violate section 202(a)(1) by "[r]efusing to regulate following an endangerment finding."

The EPA Administrator should change his previous position and should now make an endangerment finding with respect to carbon dioxide and other greenhouse gases under section 202(a)(1) of the Clean Air Act, and then should adopt an appropriate standard under section 202(a)(1) to control emissions of carbon dioxide and other greenhouse gases from new motor vehicles. To fulfill this responsibility, the EPA could adopt a standard under section 202(a)(1) that is identical to, or based upon, California's recentlyadopted regulations that set limits on the amounts of greenhouse gases that can be emitted from new motor vehicles beginning with the 2009 model year. ${ }^{193}$

Alternatively, the EPA could adopt a greenhouse gas emissions reduction standard under section 202(a)(1) that specifies a minimum miles per gallon standard for new motor vehicles. At present, the EPA contends that the only method for controlling the amount of carbon dioxide emitted by a motor vehicle is by fuel economy. ${ }^{194}$ Therefore, the EPA Administrator might adopt a fuel economy standard under section 202(a)(1) of the Clean Air Act to control carbon dioxide emissions from new motor vehicles and new motor vehicle engines which can be achieved with existing technology and at a reasonable cost. Of course, if the EPA sets a fuel economy standard for a particular class of new motor vehicles under section 202(a)(1) of the Clean Air Act that is not as strict as the DOT fuel economy standard for that class, the EPA fuel economy standard will not have a significant impact either upon global warming or upon motor vehicle manufacturers.

191. 42 U.S.C. $§ 7607(b)(9)$ (2000).

192. 415 F.3d at 81 .

193. California's regulations are analyzed infra notes 199-271 and accompanying text. 194. Massachusetts v. EPA, 415 F.3d at 80 (Tatel, J., dissenting). 
However, if the EPA sets a fuel economy standard under section 202(a)(1) for one or more particular classes of new motor vehicles under section 202(a)(1) that is stricter than the applicable DOT CAFE standard, the EPA standard may result in a significant reduction in the emissions of carbon dioxide in the United States. Because the DOT's 27.5 miles per gallon of gasoline CAFE fuel economy standard for passenger automobiles under the Energy Policy and Conservation Act has not been revised since 1986, a miles per gallon fuel economy standard for passenger automobiles of more than 27.5 miles per gallon may well be technologically achievable at a reasonable cost today, albeit through production of more high mileage small passenger automobiles and production of less low gas mileage large SUVs and pickup trucks. But with the price of gasoline at times approaching three dollars per gallon in many areas of the United States, many American consumers may support an EPA fuel economy standard that is stricter than the present CAFE standards under the EPCA.

Such a stricter fuel economy standard for passenger automobiles, sports utility vehicles and light duty pickup trucks may result in the production and sale in the United States of more fuel efficient smaller passenger automobiles and less production and sale of large, "gas guzzling" sports utility vehicles and pickup trucks, a change that motor vehicle manufacturers may make voluntarily in the near future as American consumers increasingly purchase more high gas mileage smaller passenger automobiles and fewer low gas mileage SUVs and pickup trucks. ${ }^{195}$

Reductions in carbon dioxide emissions from new motor vehicles in the United States may not significantly reduce global warming and climate changes if there are increased emissions of greenhouse gases in the future in other countries, particularly in Third World developing nations. However, reduction of emissions of greenhouse gases in the United States would result in the United States fulfilling, at least in part, its obligations under the United Nations Framework Convention on Climate Change, ${ }^{196}$ which the United States has signed and ratified, to "limit[] its anthropogenic emissions of greenhouse gases," 197 "with the aim of returning individually or jointly to their

195. Chris Woodyard, Smaller Cars Post Big Sales Increases, USA TodAy, Oct. 10, 2005, at 1B. Sales of large SUVs decreased nineteen percent in the United States during 2005 and sales of pickup trucks remained flat. Recent purchasers of pickup trucks state that fuel economy is the most important attribute of a pickup truck. Sholnn Freeman, Pickup Buyers Want Efficiency, Survey Says, WASH. Post, Nov. 17, 2005 , at D2.

196. United Nations Framework Convention on Climate Change, March 21, 1994, 1771 U.N.T.S. 107.

197. Id. at art. 4, para. 2(a). 
1990 levels these anthropogenic emissions of carbon dioxide and other greenhouse gases not controlled by the Montreal Protocol." 198

Reduction of greenhouse gas emissions within the United States also may strengthen, not weaken, the United States's attempts to influence Third World developing countries to begin to control their greenhouse gas emissions, because developing countries probably will be more likely to agree to requests by the United States to start controlling their greenhouse gas emissions if the United States has begun to control at least one significant source of its greenhouse gas emissions.

\section{State Regulation of Greenhouse Gas Emissions From New Motor Vehicles}

The California Air Resources Board has adopted regulations ${ }^{199}$ that limit the amount of emissions of greenhouse gases from new motor vehicles sold in the state beginning with the 2009 model year. This was done in response to legislation ${ }^{200}$ enacted by the California General Assembly that directed the Board to "adopt regulations that achieve the maximum feasible and costeffective reduction of greenhouse gas emissions from motor vehicles"201 "manufactured in the 2009 model year, or any model year thereafter."202 However, these state regulations probably are preempted by both section 209(a) ${ }^{203}$ of the Clean Air Act and by the Energy Policy and Conservation $\mathrm{Act}^{204}$ unless the EPA Administrator grants a waiver for the regulations under section 209(b) ${ }^{205}$ of the Clean Air Act.

The California legislation, referred to as the "California Climate Law," requires the state's greenhouse gas emission reduction regulations for new motor vehicles to be "[c] apable of being successfully accomplished within the time provided ... taking into account environmental, economic, social, and technological factors [and to be] [e]conomical to an owner or operator of a vehicle, taking into account the full-life cycle costs of a vehicle."206 In developing these regulations, the state board was required to "[c]onsider the

198. Id. at art. 4, para. 2(b).

199. Cal. Code Regs. tit. $13 \S 1961.1$ (2006).

200. Cal. Health \& Safety Code $\S 43,018.5$ (West 2005).

201. $I d$. at $\S 43,018.5(\mathrm{a})$.

202. Id. at $\S 43,018.5(\mathrm{~b})(1)$.

203. 42 U.S.C. $\$ 7543$ (a) (2000).

204. 49 U.S.C. $\$ 32,919$ (a) (2000).

205. 42 U.S.C. $\$ 7543$ (b) (2000).

206. Cal. Health \& Safety Code $\S 43,018.5$ (i)(a)-(b) (West 2005). 
technological feasibility of the regulations [and] ... the impact the regulations may have on the economy of the state." ${ }^{207}$ The board's regulations also are required to "[p] rovide flexibility, to the maximum extent feasible . . . in the means by which a person . . . may comply with the regulations." The regulations may include the use of alternative methods of compliance but not "any mandatory trip reduction measure or land use restriction." 208 The regulations adopted by the board cannot: impose any additional fees or taxes on any motor vehicle, fuel, or vehicle miles traveled; ban the sale within the state of any category of vehicle, including sport utility vehicles and light duty trucks; require reduction of vehicle weight; limit the speed limit on any highway or street within the state; or limit vehicle miles traveled. ${ }^{209}$ However, the California Climate Law "does not mandate specific reduction percentages or overall reduction goals" for greenhouse gas emissions from new motor vehicles. ${ }^{210}$

The state's greenhouse gas emission reduction regulations are to be applied to "passenger vehicle[s], light-duty truck[s], or any other vehicle[s] determined by the state board to be a vehicle whose primary use is noncommercial personal transportation." 211

The state board was required to adopt these regulations by January 1 , $2005,{ }^{212}$ but the regulations could not become effective before January 1 , 2006, "in order to give the [California] legislature time to review the

207. Id. at $\S 43,018$ (c). The Board's consideration of the economic impact of the regulations was required to include consideration of the creation of jobs and new businesses within the state, the expansion or elimination of existing businesses within the state, the ability of businesses within the state to compete with businesses in other states, "[t]he ability of the state to maintain and attract businesses in communities with the most significant exposure to air contaminants, localized air contaminants, or both, including, but not limited to, communities with minority populations or low-income populations, or both," and automobile workers and affiliated businesses within the state. $I d$. at $\S 43,018(\mathrm{c})(2)$.

208. Id. at $\S 43,018$ (c)(3). To the extent permitted by state and federal law, the board is required to grant emission reductions credits for any reductions in greenhouse gas emissions from motor vehicles that are achieved prior to the operative date of the board's greenhouse gas emissions reduction regulations, through the procedures and protocols adopted by the California Climate Action Registry under the California Health and Safety Code section 42,823(j). Id. at $\S 43,018.5(\mathrm{c})(5)(\mathrm{A})$. The baseline for calculating these emission reduction credits is the 2000 model year. $I d$. at $\S 43,018.5$ (c)(5)(B).

The greenhouse gas emission reduction regulations adopted by the board also are required to "provide an exemption for those vehicles subject to the optional low-emission vehicle standard for oxides of nitrogen ... for exhaust emission standards" in 13 Cal. Code Regs. § 1961(a)(9). Id. at $§ 43,018.5$ (e).

209. Id. at $\S 43,018(\mathrm{~d})$.

210. Deborah Keeth, Comment, The California Climate Law: A State's Cutting-Edge Efforts to Achieve Clean Air, 30 ECology L.Q. 715, 719 (2003).

211. Cal. Health \& Safety Code $§ 43,018(i)(2)$ (West 2005).

212. Id. at $\S 43,018(\mathrm{a})$. 
regulations and determine whether further legislation should be enacted prior to the effective date of the regulations." ${ }^{13}$ However,

[i]f the federal government adopts a standard regulating a greenhouse gas from new motor vehicles that the state board determines is in a substantially similar time frame, and of equivalent or greater effectiveness as the regulations that would be adopted pursuant to [the California Climate Law], the state board may elect not to adopt a standard on any greenhouse gas included in the federal standard. ${ }^{214}$

Of course, the federal government has not adopted any such standard at the present time.

The California Air Resources Board in 2004 adopted regulations under the California Climate Law establishing fleet average greenhouse gas exhaust emission standards, expressed as grams per mile carbon dioxide equivalent emissions, for new 2009 and subsequent model year passenger cars, most light duty trucks, and medium duty passenger vehicles. ${ }^{215}$ The regulations require a thirty percent reduction in greenhouse gas emissions from tailpipes of regulated new motor vehicles by 2016 . The regulations' emissions limitations encompass: (1) emissions of carbon dioxide, methane, and nitrous oxide emissions resulting directly from combustion of fuel during operation of a motor vehicle; (2) emissions of carbon dioxide resulting from operation of a vehicle's air conditioning (A/C) system; (3) emissions of hydrofluorocarbons refrigerant from a vehicle's A/C system due to leakage, losses during recharging, or release when the vehicle is scrapped at the end of its life; and (4) upstream emissions associated with production of gasoline or diesel fuel used by the vehicle.

The regulations establish a manufacturer fleet average emission standard for passenger cars and the lightest trucks, and a separate manufacturer fleet average emission standard for heavier trucks. The regulations, which take effect on January 1, 2006, establish near-term emission standards for model years 2009-2012 and mid-term emission standards for the 2013-2016 model years. Manufacturers can comply with the regulations' sales-weighted

213. Id. at $\S 43,018(\mathrm{~b})(1)$.

214. Id. at $\S 43,018.5(\mathrm{~h})$.

215. Cal. Code Regs. tit. $13 \S 1961.1$ (2006). "Light-duty trucks from 3751 lbs. LVW-8500 lbs. GVW that are certified to the Option 1 LEV [Low Emission Vehicle] II [Nitrogen Oxides] Standard in section 1961(a)(1) are exempt from these greenhouse gas emission requirements ...." Id. at § 1961.1(a). The California Office of Administrative Law approved the Board's regulations on September 15, 2005, after reviewing them to ensure that they were consistent with the California Administrative Procedures Act. The regulations and Board documents relating to and explaining its regulations for greenhouse gas emissions from motor vehicles are available at the Board's web site, http://www.arb.ca.gov/cc/cc.htm. 
average emissions standards for their fleet by choosing a mixture of technologies, from among a number of cost-effective technologies identified by the Board's staff as available to reduce greenhouse gas emissions from motor vehicles. Because the regulations' standards are expressed in terms of carbon dioxide equivalent grams per mile, emissions of the different types of greenhouse gases are weighted under the regulation to account for the differing climate change impacts of different greenhouse gases. Upstream emissions-emissions associated with the production of the fuel used by a vehicle-for motor vehicles that use conventional gasoline or diesel fuels, are used as a baseline in the regulations for comparing the relative emissions of alternative fuel vehicles whose carbon dioxide emission values will be appropriately adjusted. The regulations provide manufacturers a credit for early greenhouse gas emissions reductions in their 2000-2008 model year vehicles that meet the 2012 model year baseline standard. The regulations also provide credits to motor vehicle manufacturers for alternative methods of compliance with the regulations' standards through projects located in the state of California that achieve greenhouse gas emissions reductions through increased use of alternative fuels in eligible motor vehicles.

The California greenhouse gas emission reduction regulations for new motor vehicles may be preempted by section $209(\mathrm{a})^{216}$ of the Clean Air Act, which provides that "[n]o State or any political subdivision thereof shall adopt or attempt to enforce any standard relating to the control of emissions from new motor vehicles or new motor vehicle engines subject to [Part A of Subchapter II of the Clean Air Act (which regulates emissions from new motor vehicles and fuel)]." ${ }^{217}$ The term "emissions" is not defined by either section 209(a) or any other provision of the Clean Air Act, although section 209(a)'s reference to "emissions" when compared to section 202(a)(1)'s reference to "emission[s] of any air pollutant" (in the context of the EPA's authority to set emissions standards for new motor vehicles), suggests that section 209(a) should be interpreted broadly to preempt any state or local government standards that regulate emissions of any substance from new motor vehicles or new motor vehicle engines, not just substances that are considered to be "air pollutants" under the Clean Air Act. ${ }^{218}$ Section 209(a)

216. 42 U.S.C. $\$ 7543$ (a) (2000).

217. Section 209(a) further provides that "[n]o State shall require certification, inspection, or any other approval relating to the control of emissions from any new motor vehicle or new motor vehicle engine as condition precedent to the initial retail sale, titling (if any), or registration of such motor vehicle, motor vehicle engine, or equipment." Id.

218. In Engine Manufacturers Ass'n v. South Coast AirQuality Management District, 541 U.S. 246, 
preempts not only state laws and standards that compel manufacturers to meet specified emission limits or to equip motor vehicles with a certain type of pollution control device or design feature related to the control of emissions, but also preempts state regulations that place restrictions on the types of motor vehicles that a person may purchase or lease. ${ }^{219}$

However, because California is the only state that adopted standards, other than crankcase emission standards, for the control of emissions from new motor vehicles prior to March 30, 1966, ${ }^{220}$ the EPA Administrator is required by section 209(b)(1) ${ }^{221}$ of the Clean Air Act to waive section 209(a)'s preemption of state law if California determines that the state's standards "will be, in the aggregate, at least as protective of public health and welfare as applicable Federal standards." 222 As a result of this waiver provision new motor vehicles sold in the United States either meet federal emission control standards, promulgated under section 202 of the Clean Air Act, or California standards for which a section 209(a) waiver has been granted. ${ }^{223}$ The EPA Administrator has ruled that section 209(b)(1) waivers are not limited just to California emission control standards and regulations that address California's smog problem, and that California's air pollution problem does not have to be the worst in the United States in order for a section 209(b)(1) waiver to be granted. ${ }^{224}$

Section 209(b)(1)'s standard for a waiver permits California's "state standards to be considered as a 'package' ('in the aggregate'), rather than by evaluating each standard separately, and by permitting the state rather than the [EPA] Administrator to make the determination of whether they are 'at least as protective.", 225 This section 209(b) waiver standard therefore "confers

253 (2004), the Supreme Court stated that section 209(a) preempts state or local government standards that require a vehicle or engine not to emit "more than a certain amount of a given pollutant" but when the Supreme Court made this statement in that case it was not addressing the issue of whether section 209(a) only preempts state or local government standards that regulate emissions of a substance that is an "air pollutant" under the Clean Air Act.

219. Engine Mfrs. Ass'n v. S. Coast Air Quality Mgmt. Dist., 541 U.S. 246 (2004).

220. Ann E. Carlson, Federalism, Preemption, and Greenhouse Gas Emissions, 37 U.C. DAvis L. REv. 281, 293 (2003).

221. 42 U.S.C. $\$ 7543(b)(1)$ (2000).

222. "If each State standard is at least as stringent as the comparable applicable Federal standard, such State standard shall be deemed to be at least as protective of health and welfare as such Federal standards ...." Id. at § 7543(b)(2).

223. Motor Vehicle Mfrs. Ass'n v. N.Y. State Dep’t of Envtl. Conservation, 17 F.3d 521,526-27 (2d Cir. 1994).

224. California State Motor Vehicle Pollution Control Standards, 49 Fed. Reg. 18,887, 18,890 (May 3, 1984).

225. Note, California's Authority to Regulate Mobile Source Greenhouse Gas Emissions, 58 N.Y.U. 
broad discretion on the State of California, and affirms Congress's intent to grant California the broadest possible discretion ... to develop an emissions control program." 226

However, section 209(b)(1 $)^{227}$ provides that "[n]o such waiver shall be granted if the [EPA] Administrator finds that the state's determination is arbitrary and capricious," or if the state standards and accompanying enforcement procedures are not consistent with section 202(a) ${ }^{228}$ of the Clean Air Act. ${ }^{229}$ The EPA has ruled that a comparison of the relative costs and benefits of California's emissions control program is "not legally pertinent" in a section 209(b) waiver proceeding. ${ }^{230}$ "The meaning of "compelling and extraordinary' is somewhat ambiguous; neither courts nor the EPA have provided an explicit definition of this key phrase or the constraints it places on California's authority to regulate greenhouse gas emissions." 231 However, the EPA, in previous proceedings considering applications by California for waivers under section 209(b)(1), has interpreted the "compelling and extraordinary" standard as requiring California only to "justify[] the need for its own motor vehicle population [emissions] control program," and not the need for each particular standard and regulation that is part of the state's program. $^{232}$ Furthermore, the EPA Administrator has suggested that "compelling and extraordinary" "does not refer to levels of pollution directly,

ANN. SuRv. Am. L. 699, 720 (2003) (footnote omitted).

226. Id. (footnotes omitted).

227. 42 U.S.C. $§ 7543(b)(1)(2000)$.

228. Id. at $\S 7521$ (a).

229. Id. at $\S 7543$ (b)(1). Section 177 of the Clean Air Act provides that, notwithstanding § 209(a) of the Act, any state which has state implementation plan provisions approved under Part D of the Act [dealing with non-attainment air quality control regions that do not meet the EPA national ambient air quality standards for a particular pollutant] may adopt and enforce for any model year standards relating to control of emissions from new motor vehicles or new motor vehicle engines if such standards are identical to the California standards for which a waiver has been granted for such model year and California and such state adopts such standards at least two years before the commencement of such model year. Id. at $§ 7507$.

California's emission standards for carbon dioxide and other greenhouse gases from new motor vehicles have been adopted by eight other states (Connecticut, Maine, Massachusetts, New Jersey, New York, Oregon, Rhode Island, and Vermont). Sholnn Freeman, States Adopt California's Greenhouse Gas Limits, Wash. Post, Jan. 3, 2006, at D1. Under § 177 of the Clean Air Act, the California standards can become effective in these other states only if the EPA Administrator grants a waiver to the California standards under $\$ 209$ (b) of the Clean Air Act.

230. California State Motor Vehicle Pollution Control Standards, 49 Fed. Reg. 18,887, 18,889 (May 3, 1984).

231. Note, supra note 225 , at 722 .

232. California State Motor Vehicle Pollution Control Standards, 49 Fed. Reg. at 18,890; California State Motor Vehicle Pollution Control Standards, 58 Fed. Reg. 4166 (Jan. 13, 1993). 
but primarily to the factors that tend to produce them: geographical and climatic conditions that, when combined with large numbers and high concentrations of automobiles, create serious air pollution problems." ${ }^{233}$ The EPA's interpretation of the "compelling and extraordinary" standard in section 209(b) waiver proceedings therefore has been interpreted as:

impos[ing] only a weak constraint on California's regulatory authority. Notably, the Administrator has never invalidated a waiver on the grounds that California did not demonstrate a "compelling and extraordinary" need. Rather, California may continue to operate its own emissions program so long as it can demonstrate that as a result of its geography, climate, and large vehicle population its has a "compelling and extraordinary" need to operate a separate program from the federal government. Once California has demonstrated the need for its own program, it may impose any regulation on greenhouse gases that is in compliance with the other [section] 209 criteria. $^{234}$

Based upon these standards, and the EPA's previous interpretations of the standards governing section 209(b) waivers, the EPA Administrator should be required to issue a section 209(b) waiver to California's greenhouse gas emission reduction regulations for new motor vehicles if California applies for a waiver for the regulations after determining that its state emission control standards, including the greenhouse gas emissions control regulations, "will be, in the aggregate, at least as protective of public health and welfare as applicable Federal standards."

The EPA Administrator, however, may not grant a waiver under section 209(b)(1) to the greenhouse gas emission reduction regulations that the California Air Resources Board recently has adopted under the California Climate Law. The EPA Administrator "has sometimes denied part of a waiver [under section 209(b)(1)] or delayed implementation of California emission standards." ${ }^{235}$ Professor Ann E. Carlson has postulated that the EPA Administrator under President Bush's present administration might deny California a section 209(b)(1) waiver for California's greenhouse gas emission reduction regulations for new motor vehicles, on the grounds that California's regulations are not "necessary to meet compelling and extraordinary conditions" (because "the hardships California could experience as a result of rising temperatures are not so different from those faced by other states"), ${ }^{236}$ "that insufficient evidence exists to suggest that California will experience

233. California State Motor Vehicle Pollution Control Standards, 49 Fed. Reg. at 18,890.

234. Note, supra note 225 , at 723 .

235. Carlson, supra note 220, at 293.

236. Id. at 297-98. 
rising temperatures," and "that California regulations interfere with U.S. foreign affairs (and thus are not "necessary to meet compelling and extraordinary conditions')." ${ }^{\prime 237}$ California could argue in response that "control of greenhouse gas emissions to slow climate change is targeted at a 'compelling and extraordinary' problem within California [because] . . . in many ways California's vulnerability to climate change impacts is tied to the unique topographic and geographic conditions of the state."238

Professor Carlson also has suggested that during President Bush's second term the EPA Administrator "will almost certainly deny California's petition on the ground that carbon dioxide is not an air pollutant." ${ }^{, 239}$ She notes that the term "emissions" in section 209(a) of the Clean Air Act is not defined by the Act or the EPA regulations implementing the Act, ${ }^{240}$ and that the EPA Administrator has "broad authority" ${ }^{241}$ under section $202^{242}$ of the Clean Air Act to establish "standards applicable to the emission of any air pollutant from any class or classes of new motor vehicles or new motor vehicle engines."243 Professor Carlson explains that despite section 209(b)(1)'s waiver provision, the EPA Administrator:

[n]evertheless ... may argue that since . . carbon dioxide and other greenhouse gas emissions are not air pollutants under the [Clean Air Act], California may not regulate greenhouse gases under the waiver provision. The argument would be that the waiver provision only allows California to regulate emissions as long as the emission regulations are "at least as protective . . . as applicable Federal standards." Because the federal government does not, and under the Bush Administration's analysis cannot, regulate greenhouse gas emissions (most significantly carbon dioxide), the argument would conclude that California cannot regulate such emissions (because there are no applicable federal standards), and therefore that the California regulations are subject to the broad [Clean Air Act] preemption provision. The D.C. Circuit has held that California's power to regulate emissions is co-extensive with the EPA's power to regulate: power under Section 209(b), in other words, is identical to the EPA's power contained in section 209(a). If the D.C. Circuit is correct, the EPA could argue that as long as it lacks authority to regulate greenhouse gas emissions, so does California. ${ }^{244}$

237. Id. at 297.

238. Note, supra note 225 , at 727.

239. Carlson, supra note 220, at 293.

240. Id. at 294.

241. $I d$.

242. 42 U.S.C. $\$ 7521(2000)$.

243. Id. at $\S 7521$ (a)(1).

244. Carlson, supra note 220, at 295-96 (footnotes and citations omitted). The D.C. Circuit decision to which Professor Carlson refers is Motor Vehicle Manufacturers' Ass'n v. EPA, 627 F.2d 1095, 1110 (D.C. Cir. 1979) ("The plain meaning of the statute indicates that Congress intended to make the waiver provision coextensive with the preemption provision."). 
Professor Carlson suggests that "California could counter that if the EPA cannot regulate greenhouse gas emissions, then no state is prohibited from issuing motor vehicle greenhouse gas emissions standards, and that California need not apply for a Section 209(b) waiver." ${ }^{245}$ She adds that the EPA might respond that section 209(a)'s preemption provision "prohibits states from regulating 'emissions' from mobile sources without qualification, suggesting that states cannot regulate greenhouse gas emissions or any other emissions. ${ }^{246}$ As noted earlier, ${ }^{247}$ this argument would be supported by comparing section 209(a)'s reference to "emissions" to section 202(a)(1)'s reference to "emission[s] of any air pollutant" and concluding from this comparison that section 209(a) preempts any state standard regulating emissions of any substance, not just an "air pollutant," from new motor vehicles. Professor Carlson suggests that California, in rebuttal, could note that the term "emissions" in section 209(a) is not defined by the Clean Air Act or by EPA regulations implementing the Act, and that:

1) the EPA [under section 202(a)] is given authority to control "emissions of air pollutants," 2) the term "air pollutants" does not include greenhouse gas emissions, and 3 ) the preemption section therefore does not apply to greenhouse gas emissions ... and California . . . need not apply for a waiver under [section 209(b)(1) of the Clean Air Act $].{ }^{248}$

However, a court more likely will hold that section 209(a) preempts any state standard relating to the control of emissions of any substance (including greenhouse gases) from new motor vehicles (because section 209(a) refers to preemption of any state standard relating to emissions, not just state standards relating to emissions of air pollutants), but that the EPA Administrator can grant a waiver under section 209(b)(1) to California's greenhouse gas emissions reduction regulations for new motor vehicles.

Even if the California greenhouse gas emissions reduction regulations are not preempted by section 209(a) of the Clean Air Act (either because section 209(a) is held to be inapplicable to the California regulations or because the EPA Administrator under section 209(b)(1) grants a waiver from section 209(a) preemption), the California greenhouse gas emissions reduction regulations may be preempted by the Energy Policy and Conservation Act

245. Carlson, supra note 220, at 296.

246. $I d$.

247. See supra notes $216-18$ and accompanying text.

248. Carlson, supra note 220, at 296. 
(EPCA), ${ }^{249}$ which provides that "when an average fuel economy standard . . is in effect [under the EPCA], a State or a political subdivision of a State may not adopt or enforce a law or regulation related to fuel economy standards or average fuel economy standards for automobiles covered by an average fuel economy standard [under the EPCA]." 250 "There is no exception to this preemption, even for California, ${ }^{251}$ although, as discussed later, ${ }^{252}$ this EPCA preemption provision does not invalidate the state of California's new motor vehicle emissions regulations that have been granted a waiver by the EPA Administrator under section 209(b) of the Clean Air Act.

Under the EPCA, the Department of Transportation has established corporate average fuel economy (CAFE) standards for passenger automobiles and light duty trucks (but not for heavy duty trucks), which establish the average minimum performance standard for vehicle miles traveled per gallon of fuel for all of the models of passenger cars and light duty trucks manufactured by a particular automobile manufacturer for a particular model year. The Secretary of Transportation is required by the EPCA to set the CAFE standard at the maximum feasible level, taking into "consider[ation] technological feasibility, economic practicability, the effect of other motor vehicle standards of the [Federal] Government on fuel economy, and the need of the United States to conserve energy." 253 At the present time, the CAFE standard for passenger automobiles is 27.5 miles per gallon of gasoline ${ }^{254}$ ("or equivalent amount of other fuel"255), a standard that has not changed since $1986{ }^{256}$ The CAFE standard for light duty trucks is 21.0 miles per gallon of gasoline for model year 2005, 21.6 miles per gallon for model year 2006, and 22.2 miles per gallon for model year $2007 . .^{257}$

249. 42 U.S.C. § 32,919(a) (2000).

250. Id. The regulations are being challenged in Central Valley Chrysler-Jeep Inc. v. Witherspoon, E.D. Cal., CV-F-04-6663, on the grounds that greenhouse gases are not "air pollutants" that can be regulated by California under the Clean Air Act and that the California standards are preempted by the EPCA's fuel economy standards. Mike Ferullo, Climate Change: Lawsuits Against California Auto Standards for Carbon Dioxide May Proceed, Court Says, BNA Toxic Law Daily, Oct. 27, 2005, at http://pubs.bna.com/ip/BNA/tld.nsf/is/A0B1W5W8Z5.

251. Keeth, supra note 210 , at 725.

252. See infra notes $267-71$ and accompanying text.

253. 49 U.S.C. $§ 32902$ (f) (2000).

254. Passenger Automobile Average Fuel Economy Standards, 49 C.F.R. § 531.5(a) (2006).

255. 42 U.S.C. $\$ 32,901(a)(10)(2000)$.

256. Carlson, supra note 220, at 290-91.

257. Light Truck Fuel Economy Standards, 49 C.F.R. § 533.5(a) (2006); Light Truck Average Fuel Economy Standards Model Years 2005-2007, 68 Fed. Reg. 16,868 (Apr. 7, 2003). On August 23, 2005, the NHTSA proposed higher CAFE standards for most light trucks beginning with model years 2008-11. Average Fuel Economy Standards for Light Trucks; Model Years 2008-2011, 70 Fed. Reg. 51,414 
California's greenhouse gas emissions reduction regulations probably will require new motor vehicles to achieve greater fuel economy in order to reduce their emissions of greenhouse gases to the extent required by the regulations, because "[n]o technology currently exists or is under development that can capture and destroy or reduce emissions of [carbon dioxide] . . . from motor vehicle tailpipes. At present, the only practical way to reduce tailpipe emissions of [carbon dioxide] is to improve fuel economy." 258

Although California's greenhouse gas emissions reduction regulations under the California Climate Law avoid clear preemption by the EPCA's CAFE standards by not explicitly specifying fuel economy standards (e.g., average miles per gallon requirements) for new motor vehicles, the California regulations may be preempted by the EPCA's CAFE standards because the California regulations probably will require motor vehicle manufacturers to reduce greenhouse gas emissions principally by reducing carbon dioxide emissions by improving the fuel economy of their new motor vehicles. "Since directly regulating fuel economy would create tension with EPCA's preemption clause, California ... instead require[s] manufacturers [of new motor vehicles] to install a range of technological measures that result in reduced [carbon dioxide] emissions, without specifying fuel economy targets." ${ }^{259}$ Such technological improvements might include: engine improvements such as improved specific power and gasoline direct injection; improved transmissions, such as 5- and 6-speed automatic transmissions, 5 -speed motorized manual gearshifts, and continuously variable transmissions; integrated starter generators that shut off idling engines; and hybrid electric drive trains. ${ }^{260}$ However, because methods to reduce carbon dioxide emissions "directly relate to fuel efficiency," since reduction of carbon dioxide emissions makes a motor vehicle more fuel efficient, ${ }^{261}$ the EPCA may preempt and invalidate California's greenhouse gas emissions reduction regulations because the regulations will require reduction of greenhouse gas

(Aug. 30, 2005). The 2011 model year standards would divide light trucks into four categories based on size, with a standard of 28.4 miles per gallon for the lightest trucks and 21.2 miles per gallon for the largest light trucks.

258. Control of Emissions from New Highway Vehicles and Engines, 68 Fed. Reg. 52,922, 52,929 (Sept. 8, 2003) (EPA Administrator's denial of petition to regulate greenhouse gas emissions under section 202(a)(1) of the Clean Air Act). "[A] more fuel-efficient vehicle emits less [carbon dioxide] per mile traveled in direct proportion to the increase in its fuel efficiency." Christopher T. Giovinazzo, Comment, California's Global Warming Bill, 30 Ecology L.Q. 893, 924 (2003).

259. Giovinazzo, supra note 258, at 924.

260. Control of Emissions from New Highway Vehicles and Engines, 68 Fed. Reg. at 52,925.

261. Giovinazzo, supra note 258, at 924. 
emissions from new motor vehicles primarily by methods or measures that increase a vehicle's fuel efficiency/economy.

The National Highway Traffic Safety Administration (NHTSA), in commentary accompanying its recent proposed revised CAFE standards for light duty trucks, has stated that "[a] state law that seeks to reduce motor vehicle carbon dioxide emissions is both expressly and impliedly preempted" by the EPCA. ${ }^{262}$ The NHTSA reasons that "since the way to reduce carbon dioxide emissions [from motor vehicles] is to improve fuel economy, a state regulation seeking to reduce those emissions is a 'regulation related to fuel economy standards or average fuel economy standards' within the meaning of [the EPCA's preemption provision]. ${ }^{263}$ This interpretation of the EPCA by the NHTSA probably is not entitled to deference by a court under the Chevron doctrine, even if it is a reasonable interpretation by an administrative agency of an ambiguous federal statute, because this interpretation is not presented in a formal agency regulation that was subject to public notice and comment or a formal adjudication decision. ${ }^{264}$ However, the NHTSA expresses the legal theory upon which the federal government probably will rely in trying to have the EPCA preempt and invalidate the California carbon dioxide emissions reduction regulations for new motor vehicles.

The NHTSA's interpretation of the EPCA's preemption provision arguably is supported by some decisions ${ }^{265}$ of the United States Supreme Court, interpreting provisions in other federal statutes that provide that specified federal laws preempt state laws "relating" to specific matters, which support an interpretation of the EPCA's preemption clause under which

262. Average Fuel Economy Standards for Light Trucks; Model Years 2008-2011, 70 Fed. Reg. at 51,457 .

263. Id. The NHTSA also reasons that such a state regulation is impliedly preempted by the EPCA because it would interfere with the NHTSA's implementation of the EPCA:

For example, [such a state regulation] would interfere [with] the careful balancing of various statutory factors and other related considerations, as contemplated in the conference report on EPCA, we must do in order to establish average fuel economy standards at the maximum feasible level. It would also interfere with our effort to reform CAFE, so as to achieve higher fuel savings, while reducing the risk of adverse economic and safety consequences.

Average Fuel Economy Standards for Light Trucks; Model Years 2008-2011, 70 Fed. Reg. at 51,457.

264. Christensen v. Harris County, 529 U.S. 576, 587 (2000) ("Interpretations contained in policy statements, agency manuals, and enforcement guidelines ... do not warrant Chevron-style deference.").

265. E.g., Morales v. Trans World Airlines, Inc., 504 U.S. 374, 378-79 (1992) (interpreting a provision of the Airline Deregulation Act of 1978 which provides that federal law expressly preempts state laws "relating to rates, routes, or services of airlines"); Metro. Life Ins. Co. v. Massachusetts, 471 U.S. 724, 739 (1985) (interpreting a provision of the Employee Retirement Income Security Act of 1974 (ERISA) that preempts states' laws which "relate to" employee benefit plans subject to the ERISA). 
"California is broadly preempted from promulgating regulations related to fuel economy standards regardless of the CAA waiver."

On the other hand, one commentator ${ }^{267}$ has argued that more recent Supreme Court decisions, ${ }^{268}$ interpreting the preemption provision ${ }^{269}$ in the Employee Retirement Income Security Act of 1974 (ERISA) (which provides that the ERISA preempts any state law which "relate[s] to any employee benefit plan" subject to the ERISA), support an interpretation of section 209(b) of the Clean Air Act and the EPCA's preemption provisions under which California's greenhouse gas emission reduction regulations for new motor vehicles, for which EPA has granted a waiver under section 209(b) of the Clean Air Act, would not be preempted by the EPCA's preemption provision that bans state laws relating to fuel economy. ${ }^{270}$ One basis for this argument is that if the EPA Administrator grants a waiver under section 209(b) of the Clean Air Act to California greenhouse gas emissions reduction regulations, the California regulations would be a federal standard for purposes of the EPCA, not a state standard or law subject to preemption under the EPCA. ${ }^{271}$ This argument is a sound one, and should be the basis for rejection of the NHTSA's interpretation of the EPCA's preemption provision if the EPA grants a Clean Air Act section 209(b) waiver to California's greenhouse gas emissions reduction regulations. However, the EPCA preemption provision may invalidate the California greenhouse gas emissions reduction regulations if the EPA Administrator does not grant a waiver for such regulations under section 209(b) of the Clean Air Act.

\section{State Regulation of Greenhouse Gas Emissions From In-use ON-ROAd Motor Vehicles}

Subject to specified Clean Air Act preemption provisions (including section 209(a) and section 211(c)(4) ${ }^{272}$ which generally preempt state and

266. Giovinazzo, supra note 258, at 929.

267. Id. at 929-32.

268. N.Y. State Conference of Blue Cross \& Blue Shield Plans v. Travelers Ins. Co., 514 U.S. 645 (1995); Cal. Div. of Labor Standards Enforcement v. Dillingham Constr., Inc., 519 U.S. 316 (1997).

269. 29 U.S.C. $\$ 1144(a)$ (2000).

270. Giovinazzo, supra note 258 , at $929-53$.

271. Id. at 948-50. This argument is premised in part upon the fact that the "EPCA defined 'federal standards' to include both national motor vehicle standards as well as 'emissions standards applicable by reason of section 209(b),' the waiver provision of the [Clean Air Act]." Id. at 949 (citing Energy Policy and Conservation Act, Pub. L. No. 94-163, § 502(d)(3)(D)(I-ii), 89 Stat. 871, 905 (1975)).

272. 42 U.S.C. $\$ 7545(c)(4)$ (2000). 
local government controls or prohibitions of characteristics or components of motor vehicle fuels or fuel additives for purposes of motor vehicle emission control), section $116^{273}$ of the Clean Air Act provides that nothing in the Clean Air Act:

shall preclude or deny the right of any State or political subdivision thereof to adopt or enforce (1) any standard or limitation respecting emissions of air pollutants or (2) any requirement respecting control or abatement of air pollution; except that if an emission standard or limitation is in effect under an applicable implementation plan or under section 111 or 112 of [the Clean Air Act], such State or political subdivision may not adopt or enforce any emission standard or limitation which is less stringent than the standard or limitation under such plan or section. ${ }^{274}$

Consequently, because section 209(a) only prohibits a state or political subdivision from adopting or attempting to enforce a standard relating to the control of emissions from new motor vehicles or new motor vehicle engines, the Clean Air Act does not preclude a state or local government from imposing its own emission control standards upon an in-use on-road motor vehicle upon resale or re-registration of the vehicle after the formerly new motor vehicle is passed on to the ultimate consumer purchaser. ${ }^{275}$ Following registration of a formerly new motor vehicle by the ultimate consumer purchaser, the vehicle is no longer a "new" motor vehicle under the Clean Air Act and section 209(a) "lapses by its own terms."276

Relying upon this authority under section 116 to regulate emissions of air pollutants from in-use on-road motor vehicles, a state might seek to control greenhouse gas emissions from those vehicles by reducing the maximum permissible speed on highways ${ }^{277}$ or by placing restrictions on the miles that a particular motor vehicle could travel, such as permitting a particular motor vehicle to be driven on commuter roads and highways only three or four weekdays per week. However, either of these types of restrictions might be opposed by large numbers of members of the public. ${ }^{278}$

273. 42 U.S.C. $\S 7416(2000)$.

274. $I d$.

275. Allway Taxi, Inc. v. City of New York, 340 F. Supp. 1120, 1124 (S.D.N.Y. 1972), aff'd per curiam, 468 F.2d 624 (2nd Cir. 1972); Frame Factory, Inc. v. Dep't of Ecology, 583 P.2d 660, 663 (Wash. Ct. App. 1978).

276. Metro Systems Corp. v. City of New York, 12 Env't Rep. Cas. (BNA) 1822 (S.D.N.Y. 1979).

277. "Cars are designed to drive most efficiently at around 60 m.p.h.; efficiency drops $7 \%$ to $23 \%$ for every 5 m.p.h. over that." Lisa Takeuchi Cullen, How to Save $\$ \$ \$$ Now, Time, Oct. 31, 2005, at 64 . Consequently, cars driven over 60 m.p.h. on highways will burn more gasoline per distance traveled than at 60 m.p.h. and therefore will emit more carbon dioxide per distance traveled at such higher speeds.

278. California's General Assembly has prohibited the California Air Resources Board from 
A state or local government is not preempted by section 209(a) of the Clean Air Act from requiring older in-use on-road vehicles to be retrofitted to become equipped with emission control devices which comply with specified Clean Air Act emission control standards for later model new motor vehicles. ${ }^{279}$ A state or local government also is not preempted by the Clean Air Act from requiring an owner of an in-use on-road motor vehicle from insuring the installation and upkeep of federally required Clean Air Act emission control devices in the motor vehicle. ${ }^{280}$ Section 209(a) also does not preempt a state law that makes it illegal for a person to remove, from an in-use on-road motor vehicle, pollution control equipment (such as a catalytic converter) required by Clean Air Act emission control requirements. ${ }^{281}$

Consequently, if the EPA Administrator in the future should adopt emission standards for carbon dioxide or other greenhouse gases for new motor vehicles or engines under section 202(a)(1), a state or local government would not be preempted by the Clean Air Act from adopting standards requiring owners of motor vehicles subject to such EPA section 202(a)(1) greenhouse gas emission standards to have their vehicles: 1) periodically inspected to determine if the motor vehicles' emissions of greenhouse gases are in compliance with the EPA's section 202(a)(1) emissions standards, both during the vehicle's useful life ${ }^{282}$ and thereafter; and 2) to require a vehicle that failed the EPA's section 202(a)(1) standards (or a stricter standard adopted by the state for in-use on road motor vehicles) to be repaired in order to comply with the applicable emissions standards. The Clean Air Act also would not preempt a state or local government from requiring an older model motor vehicle, that is not subject to any EPA section 202(a)(1) greenhouse gas emissions standards, to be retrofitted in order to comply with the EPA section 202(a)(1) greenhouse gases emissions standards or state greenhouse gases emissions standards for in-use on-road motor vehicles.

A state or local government is prohibited by the Clean Air Act from imposing its own emission control standards upon a motor vehicle "the

\footnotetext{
including such restrictions in the Board's greenhouse gas emissions reduction regulations for new motor vehicles. Cal. Health \& SAFety Code $§ 43,018.5(d)(4) \&(5)$ (West 2005).

279. Allway Taxi, Inc., 340 F. Supp. at 1124.

280. Id. at 1124 n.7.

281. Frame Factory, Inc. v. Dep’t of Ecology, 583 P.2d 660, 663 (Wash. Ct. App. 1978). A state or local government also is not preempted by section 209(a) of the Clean Air Act from setting its own standards for the licensing of motor vehicles for commercial use within the government's territory. Allway Taxi, Inc., 340 F. Supp. at 1124.

282. As discussed supra note 26 and accompanying text, section 202(a)(1) emissions standards are applicable to motor vehicles and engines for their useful life.
} 
moment after the new motor vehicle is bought and registered." ${ }^{283}$ A state is precluded by section 209(a) of the Clean Air Act from imposing state standards or penalties upon a manufacturer of new motor vehicles or new motor vehicle engines for producing a motor vehicle engine that is designed to circumvent Clean Air Act emissions standards for new motor vehicles or new engines because section 209(a) preempts a state from seeking to impose state penalties to provide a manufacturer with an incentive to comply with the federal standards. ${ }^{284}$ Consequently, if the EPA Administrator in the future does adopt a greenhouse gases emissions standard for new motor vehicles and engines under section 202(a)(1) of the Clean Air Act, a state or local government could not seek to impose sanctions or penalties under state law upon a manufacturer who produced a new motor vehicle or engine that emits greenhouse gas emissions in amounts that violate the EPA's section 202(a)(1) standard.

However, even if a state or local government standard to regulate carbon dioxide emissions from in-road in-use motor vehicles is not preempted by the Clean Air Act, such a state or local government standard may be preempted by the provision ${ }^{285}$ of the EPCA that prohibits any state or local government from adopting a law or regulation "related to fuel economy standards or average fuel economy standards for automobiles covered by an average fuel economy standard under this chapter." ${ }^{286}$ This preemption provision makes no distinction between state standards for new motor vehicles and state standards for in-use on-road motor vehicles, although one could argue that the provision's reference to "automobiles covered by an average fuel economy standard under this chapter" implicitly refers only to new motor vehicles covered by a CAFE standard issued under the EPCA. However, if this EPCA preemption provision is held applicable to state standards for both new motor vehicles and in-use on-road motor vehicles, any state or local government regulation seeking to reduce carbon dioxide emissions from an in-use on-road motor vehicles would be preempted by the EPCA, because such a regulation would have to seek to reduce a vehicle's carbon dioxide emissions by increasing the vehicle's fuel efficiency. Such a state or local government regulation therefore probably would be held to "relate to fuel economy" and to be preempted by the EPCA under analysis similar to that which would be

283. AllwayTaxi, Inc., 340 F. Supp. at 1124 (dictum); Detroit Diesel Corp. v. Att'y Gen., 269 A.D.2d 1, 8 (N.Y. App. Div. 2000).

284. Detroit Diesel Corp., 269 A.D.2d at 9-10.

285. 49 U.S.C. $\$ 32,919$ (a) (2000).

286. This preemption provision is discussed supra notes $249-71$ and accompanying text. 
followed for state or local government requirements to reduce carbon dioxide emissions from new motor vehicles and engines. ${ }^{287}$

Because the present EPA Administrator has decided that greenhouse gases (including carbon dioxide) are not air pollutants under the Clean Air Act and therefore cannot be criteria air pollutants under section $108(a),{ }^{288}$ for which a national ambient air quality standard (NAAQS) has to be established under section $109^{289}$ of the Clean Air Act ${ }^{290}$ state governments are not currently required to regulate emissions of carbon dioxide from stationary and mobile sources (including motor vehicles) under section $110^{291}$ of the Clean Air Act. If the EPA in the future does establish a section 109 NAAQS for carbon dioxide, each state would have to add provisions to their section 110 Clean Air Act implementation plan(s) to control emissions of carbon dioxide from stationary and mobile sources as necessary to attain and maintain the NAAQS for carbon dioxide. ${ }^{292}$ The extent to which a section 110 state implementation plan, for a particular air quality control region, would have to regulate emissions of carbon dioxide from in-use on-road motor vehicles operating within the region, would depend upon particular characteristics of each air quality control region subject to a section 110 state implementation plan, including the level of concentrations of carbon dioxide in the ambient air of that region compared to the maximum concentrations of carbon dioxide permitted by the EPA's NAAQS for carbon dioxide, the amounts of carbon dioxide emitted into the region's ambient air by stationary sources (including fossil-fuel burning electric utility generating plants) located within the region, the amount of carbon dioxide emitted into the region's ambient air by in-use on-road motor vehicles operating within the region, and the amount of carbon

287. See supra notes 259-71 and accompanying text which analyzes the EPCA's possible preemption of a state government greenhouse gas emission reduction requirement for new motor vehicles and engines.

288. 42 U.S.C. $\$ 7408$ (a) (2000).

289. Id. at $\S 7409$.

290. The EPA Administrator in his decision to deny the petition to set standards under section 202(a)(1) of the Clean Air Act for greenhouse gases emissions from new motor vehicles and new motor vehicle engines stated that greenhouse gases (including carbon dioxide) "are not air pollutants under the [Clean Air Act's] regulatory provisions, including sections 108, 109, 111, 112, and 202." Control of Emissions from New Highway Vehicles and Engines, 68 Fed. Reg. 52,922, 52,928 (Sept. 8, 2003). During the summer of 2003, the EPA Administrator denied a petition filed by eleven states to list carbon dioxide as a criteria pollutant under section 108 of the Clean Air Act. David R. Hodes, State Law Responses to Global Warming, 21 PACE EnvtL. L. Rev. 53, 56 (2003). Janine Maney argues that the EPA Administrator has a non-discretionary duty under section 108 of the Clean Air Act to list carbon dioxide as a criteria pollutant under section 108. Janine Maney, Carbon Dioxide Emissions, Climate Change, and the Clean Air Act, 13 N.Y.U. ENVTL. L.J. 298, 376 (2005).

291. 42 U.S.C. $\$ 7410(2000)$.

292. Id. at $\S 7410(\mathrm{a})(1) \&(2)(\mathrm{A})$. 
dioxide that is emitted by stationary sources and motor vehicles operating outside the region that is transported into the particular air quality control region.

If section 109 NAAQS are established for carbon dioxide, and if the EPA Administrator establishes carbon dioxide emission standards for new motor vehicles under section 202(a)(1) of the Clean Air Act, then each state might have to add to their section 110 state implementation plan(s) provisions requiring inspection and maintenance programs for in-use on-road vehicles. Such inspection/maintenance programs, which presently are required to be present in section 110 state implementation plans for ozone non-attainment areas, ${ }^{293}$ would require each motor vehicle registered in a particular air quality control region to be tested periodically to determine if the vehicle is in compliance with the section 202(a)(1) carbon dioxide emission standards for the useful life of the vehicle and would require necessary repairs (up to a specified dollar amount) of the vehicle if the vehicle violates the section 202(a)(1) standard during its useful life. ${ }^{294}$ However, such an inspection/ maintenance program only would be required if necessary to attain and maintain the carbon dioxide NAAQS in a particular air quality control region. If such section 110 state implementation plan provisions are approved by the EPA Administrator, or if such plan provisions are imposed upon a state by the EPA Administrator under section $110(c)(1)^{295}$ as a Federal implementation plan, these plan provisions should be considered federal regulations that are not subject to preemption under the EPCA. ${ }^{296}$

The EPA Administrator, however, opposes both the listing of carbon dioxide as a criteria pollutant under section 108 of the Clean Air Act and state regulation of carbon dioxide emissions under section 110 implementation plans, because concentrations of carbon dioxide in the earth's atmosphere are fairly uniform throughout the world, requiring worldwide programs involving carbon dioxide emissions controls by all nations in order to be effective: ${ }^{297}$

293. 42 U.S.C. §§ $7511 \mathrm{a}(2)(B),(b)(4),(c)(3)$ (2000).

294. The "useful life" of a motor vehicle, for purposes of the EPA new motor vehicle emissions standards, is discussed supra note 26 and accompanying text.

295. 42 U.S.C. at $\S 7410(c)(1)$.

296. 49 U.S.C. $\$ 32,919$ (a) (2000). As discussed supra notes 267-71 and accompanying text, a similar argument, that a grant by the EPA Administrator of a waiver to California new motor vehicle emissions standards makes those California standards federal standards for purposes of the EPCA's preemption provision, is presented in Giovinazzo, supra note 258, at 948-50.

297. Control of Emissions from New Highway Vehicles and Engines, 68 Fed. Reg. 52,922, 52,927 (Sept. 8, 2003). 
Such a situation would be inconsistent with a basic underlying premise of the [Clean Air Act ] regime for implementation of a NAAQS - that actions taken by individual states and by EPA can generally bring all areas of the U.S. into attainment of a NAAQS. The statutory NAAQS implementation regime is fundamentally inadequate when it comes to a substance like [carbon dioxide], which is emitted globally and has relatively homogenous concentrations around the world. A NAAQS for [carbon dioxide], unlike any pollutant for which a NAAQS has been established, could not be attained by any area of the U.S. until such a standard were attained by the entire world as a result of emission controls implemented in countries around the world. ${ }^{298}$

However, state programs, under section 110 implementation plans to control carbon dioxide emissions from both stationary and mobile sources, would fulfill at least part of the duties of the United States under the Climate Change Framework Convention (which the United States has ratified) and the Kyoto Protocol (which the United States has signed but not ratified). At the very least, the respect and cooperation extended to the United States by other nations should significantly improve if the United States significantly reduces this nation's emissions of carbon dioxide from motor vehicles and stationary sources, as a result of EPA promulgation of carbon dioxide emission standards for new motor vehicles per section 202(a)(1), and of controls of carbon dioxide emissions under section 110 state implementation plans.

\section{EPA Regulation of Emissions of Hazardous Air Pollutants From New Motor Vehicles}

Because greenhouse gases (carbon dioxide, methane, nitrous oxide and hydrofluorocarbons) presently are not listed as hazardous air pollutants under section 112(b)(1) ${ }^{299}$ of the Clean Air Act, and the present EPA Administrator has stated ${ }^{300}$ that greenhouse gases are not "air pollutants" under the Clean Air Act's regulatory provisions in section 112 for hazardous air pollutants, the present EPA Administrator probably will not establish regulations under section 202(1)(2) $)^{301}$ that would require control of greenhouse gas emissions as hazardous air pollutant emissions from motor vehicles and motor vehicle fuels.

Section 202(1)(2) of the Clean Air Act required the EPA Administrator, by May 15, 1995, to promulgate regulations, under section 202(a)(1) ${ }^{302}$ or

298. Id.

299. 42 U.S.C. $\$ 7412$ (b)(1) (2000).

300. Control of Emissions from New Highway Vehicles and Engines, 68 Fed. Reg. at 52,928.

301. 42 U.S.C. $\$ 7521(1)(2)(2000)$.

302. Id. at $\S 7521(\mathrm{a})(1)$. 
section 211(c)(1), ${ }^{303}$ “containing reasonable requirements to control hazardous air pollutants from motor vehicles and motor vehicle fuel." Although this provision refers to "motor vehicles" rather than to "new motor vehicles" (as is the case in section 202(a)(2)), the EPA Administrator has interpreted section 202(1)(2) as only giving him authority to adopt regulations to control hazardous air pollutant emissions from new motor vehicles and as not giving him authority to promulgate hazardous air pollutant emission regulations for in-use on-road motor vehicles. ${ }^{304}$ A panel of the United States Court of Appeals for the District of Columbia has upheld this EPA interpretation of section 202(1)(2), stating that "we cannot read § 202(1)(2)'s omission of the word 'new' as carte blanche to regulate in-use vehicles in connection with toxics." "305

Section 202(1)(2) as drafted authorizes the EPA Administrator to control emissions of hazardous air pollutants from motor vehicles solely through regulations issued under section 211(c)(1) that control fuels and fuel additives to protect public health or welfare, although under section 202(1)(2) the EPA Administrator probably could control emissions of hazardous air pollutants from new motor vehicles both through section 202(a)(1) emissions standards and through section 211(c)(1) regulations controlling fuels and fuel additives.

These regulations under section 202(1)(2), which are required, at a minimum, to apply to emissions of benzene and formaldehyde, "shall not be inconsistent with standards under [section 202(a)]" and "shall contain standards for such fuels or vehicles, or both, which the [EPA] Administrator determines reflect the greatest degree of emission reduction achievable through the application of technology which will be available, taking into consideration the standards established under [section 202(a)(1)], the availability and costs of the technology, and noise, energy, and safety factors, and lead time." 306

Although section 202(1)(2) states that regulations issued under its directives shall apply at a minimum to emissions of benzene and formaldehyde, section 202(1)(2) does not define "hazardous air pollutants" for purposes of its requirements. Although section 112(a)(6) ${ }^{307}$ defines

303. Id. at $\S 7545(\mathrm{c})(1)$.

304. Sierra Club v. EPA, 325 F.3d 374, 380 (D.C. Cir. 2003).

305. Id. at 382 . The court consequently rejected claims by several states that the EPA was required to consider adopting controls under section 202(1)(2) for in-use heavy duty vehicles. $I d$. at 380 .

306. 42 U.S.C. $\$ 7521(1)(2)(2000)$.

307. Id. at $\S 7412(\mathrm{a})(6)$. 
"hazardous air pollutant" as any air pollutant listed pursuant to $112(\mathrm{~b})(1)^{308}$ (which presently lists 188 substances as "hazardous air pollutants") or which the EPA Administrator has listed under section 112(b)(2) or (3) ${ }^{309}$ of the Clean Air Act, ${ }^{310}$ a panel of the United States Court of Appeals for the District of Columbia has held that 'this definition applies only 'for purposes' of § [112] itself (except for subsection (r)), and has no bearing on the term as it appears in $\S 202(1)(2) . " 311$ The EPA's present position is that "hazardous air pollutants" for purposes of section 202(1)(2) "are those pollutants known or suspected to cause cancer or other serious health or environmental effects" and that section 202(a)(1) allows it to address air pollution that impacts health or welfare. ${ }^{313}$ The EPA's initial regulatory efforts under section 202(1)(2), however, are focused on 21 compounds, including benzene and formaldehyde, that are known or suspected to cause cancer or other serious health effects, although "[a]dditional compounds may be added in the future due to their ecological impacts, material damage, or visibility impairment." 314

Because the present EPA Administrator has declined to list greenhouse gases as hazardous air pollutants under section 112 of the Clean Air Act, he probably also will decline to list them as "hazardous air pollutants" under section 202(1)(2). Section 112(b)(2) $)^{315}$ states that the EPA Administrator "shall periodically ... where appropriate, revise [the] list [of hazardous air pollutants established by section 112(b)] by rule, adding pollutants which present, or may present, through inhalation or other routes of exposure, a threat of adverse human health effects . . . or adverse environmental effects whether through ambient concentrations, bioaccumulation, deposition, or otherwise, but not including [accidental] releases under [section 112(r)]." The greenhouse gas hydrofluorocarbons cannot be listed as a section 112 hazardous air pollutant "solely due to its adverse effects on the environment" because hydrofluorocarbons are substances regulated under subchapter VI [ozone depleting substances] of the Clean Air Act. ${ }^{316}$ However, this prohibition does not apply to the listing of hydrofluorocarbons as "hazardous

308. Id. at $\S 7412(\mathrm{~b})(1)$.

309. Id. at $\S 7412$ (b)(2) \& (3).

310. Sierra Club, 325 F.3d at 383.

311. Id.

312. Control of Emissions of Hazardous Air Pollutants from Mobile Sources, 66 Fed. Reg. 17,230, 17,231 (Mar. 29, 2001).

313. Id. at 17,234 n. 4 .

314. Id. at 17,231.

315. 42 U.S.C. $§ 7412(b)(2)(2000)$.

316. $I d$. 
air pollutants" under section 202(1)(2). Section 112 also provides that no air pollutant which is listed as a criteria pollutant under section 108(a) can be listed as a hazardous air pollutant under section 112, although that prohibition does "not apply to any pollutant which independently meets the listing criteria of [section 112(b)(2)] and is a precursor to a pollutant which is listed under section 108(a) or to any pollutant which is in a class of pollutants listed under such section." This latter provision of section 112 should be interpreted to mean that the greenhouse gas nitrous oxides could be listed as a section 112 hazardous air pollutant even though oxides of nitrogen is listed as a criteria pollutant under section 108(a). In any case, this prohibition as to listing under section 112 would not be applicable to the listing of nitrous oxides as a hazardous air pollutant under section 202(l)(2) of the Clean Air Act.

Although greenhouse gases (including carbon dioxide) probably might not be found to present a threat of adverse health effects as a result of their contributions to global warming and climate change, they might well be found to present a threat of adverse environmental effects due to their contributions to global warming and climate change. This would justify listing them as hazardous air pollutants under either section 202(1)(2) or section 112 on the basis of the threat of their causing adverse environmental effects. Section 112(b)(3)(B) provides:

The Administrator shall add a substance to the list upon a showing by [a] petitioner or on the Administrator's own determination that the substance is an air pollutant and that emissions, ambient concentrations, bioaccumulation or deposition of the substance are known to cause or reasonably may be anticipated to cause adverse effects to human health or adverse environmental effects. ${ }^{317}$

After the EPA Administrator was sued for failing to promulgate regulations under section 202(1)(2) to control emissions of hazardous air pollutants from motor vehicles by May 15, 1995, as required by section 202(1)(2) of the Clean Air Act, the EPA Administrator, pursuant to a consent decree, issued regulations in March $2001^{318}$ to control the emissions of hazardous air pollutants from motor vehicles under section 202(1)(2). In commentary accompanying these regulations, the EPA Administrator noted that emissions of air toxics from "a wide variety of mobile sources" already

317. Id. at $\S 7412(\mathrm{~b})(3)(\mathrm{B})$.

318. Control of Emissions of Hazardous Air Pollutants from Mobile Sources, 66 Fed. Reg. at $17,262-73$ 
have been reduced by "many of the emission control programs put in place pursuant to the 1990 Clean Air Act amendments:" ${ }^{19}$

These include our reformulated gasoline (RFG) program, which has substantially reduced mobile source air toxics, particularly in urban areas which often have high levels of ambient air toxics, our national low emission vehicle (NLEV) program, our Tier 2 motor vehicle emissions standards and gasoline sulfur control requirements, and standards for nonroad vehicles and equipment, such as locomotives, recreational marine engines, and aircraft. We have also proposed heavy-duty engine and vehicle standards and onhighway diesel fuel sulfur control requirements that would reduce toxics emissions from heavy-duty trucks. Finally, certain other mobile source control programs have been specifically aimed at reducing toxics emissions from mobile sources (e.g., our lead phaseout program).

While these mobile source standards were put in place primarily to reduce ambient concentrations of criteria pollutants through oxides of nitrogen . . . , volatile organic compound $[\mathrm{s}]$. . . , carbon monoxide ... and particulate matter ... controls, and thereby to help states and localities come into attainment with the National Ambient Air Quality Standards ... for ozone, [particulate matter], and [carbon monoxide], they have reduced and will continue to reduce the levels of on-highway emissions of air toxics significantly. By 2020, we project these programs will reduce the levels of on-highway emissions of benzene by 73 percent, formaldehyde by 76 percent, 1,3-butadiene by 72 percent, and acetaldehyde by 67 percent from 1990 levels. ${ }^{320}$

Some of these section 202(1)(2) regulations adopted in March 2001, promulgated under section 211 (c)(1) ${ }^{321}$ to regulate motor vehicle fuels and fuel additives, impose an "anti-backsliding" requirement upon fuel refineries and importers that mandates that they maintain current levels of controls of toxic and hazardous substances in motor vehicle gasoline that exceed the levels of controls required by the EPA's present regulations. ${ }^{322}$ However, these regulations "do not require [gasoline] refiners to install new equipment or use technologies beyond what they were using in the baseline period (19982000)."."323

Furthermore, these regulations do not impose any new requirements for control of emissions of hazardous air pollutants from motor vehicles, although one of the adopted regulations states, in part, that:

no later than July 1, 2003, the Administrator shall propose any requirements to control hazardous air pollutants from motor vehicles and motor vehicle fuels that the Administrator determines are appropriate pursuant to section 202(1)(2) of the [Clean Air]

319. Id. at 17,232 .

320. Id. (footnotes omitted).

321. 42 U.S.C. $\$ 7545(c)(1)(2000)$.

322. Control of Emissions of Hazardous Air Pollutants from Mobile Sources, 66 Fed. Reg. at 17,245.

323. Id. at 17,230. 
Act. The Administrator will take final action on such proposal no later than July 1, $2004 . .^{324}$

In commentary accompanying these regulations, the EPA Administrator listed twenty-one mobile source air toxics, including benzene and formaldehyde (but not any of the greenhouse gases), emitted by motor vehicles, that are known or suspected to cause cancer or other serious health effects, as potential hazardous air pollutants whose emissions might be regulated under section 202(1)(2) standards. ${ }^{325}$

The EPA stated that it was not establishing new standards to regulate emissions of hazardous air pollutants from motor vehicles at that time because it had "determined that [the EPA's] proposed and current control programs for [volatile organic compounds] and diesel [particulate matter] emissions from motor vehicles will achieve the greatest degree of [motor vehicle hazardous air pollutant emissions] control that is feasible when cost and other relevant factors are considered." ${ }^{326}$

After these regulations were upheld by the United States Court of Appeals for the District of Columbia, ${ }^{327}$ the EPA failed to propose or promulgate any regulations by the deadlines specified in the regulation. ${ }^{328} \mathrm{~A}$ federal district court subsequently held that the "plain language" of this EPA regulation under section 202(1)(2) "create[s] a nondiscretionary duty requiring the Administrator to act by specified dates," 329 "to either affirmatively act or decide that no action was needed, ${ }^{330}$ and that the EPA Administrator's failure to perform this nondiscretionary duty could be challenged in a citizen suit brought under section 304(a)(2) ${ }^{331}$ of the Clean Air Act. ${ }^{332}$

In response to this decision, the EPA recently entered into a consent decree in which it has agreed to promulgate, by February 9, 2007, regulations under section 202(1)(2) to limit emissions of twenty-one hazardous air pollutants, including benzene, formaldehyde, and 1,3 butadiene, from new

324. 40 C.F.R. $\$ 80.1045$; Control of Emissions of Hazardous Air Pollutants from Mobile Sources, 66 Fed. Reg. at 17,272-73.

325. Control of Emissions of Hazardous Air Pollutants from Mobile Sources, 66 Fed. Reg. at 17,236. 326. Id. at 17,241.

327. Sierra Club v. EPA, 325 F.3d 374 (D.C. Cir. 2003). This decision, and the regulations which it upheld, are analyzed in Sky Stanfield, Note, The Mobile Source AirToxics Rule: How Does the Greatest Reduction Become No Reduction?, 31 Ecology L.Q. 563 (2004).

328. Sierra Club v. Leavitt, 355 F. Supp. 2d 544, 546 (D.D.C. 2005).

329. Id. at 557.

330. Id. at 550 .

331. 42 U.S.C. $\$ 7604(a)(2)(2000)$.

332. Sierra Club. v. Leavitt, 355 F. Supp. $2 d$ at 557. 
motor vehicles. ${ }^{333}$ The consent decree does not specify the extent to which these new regulations will control hazardous air pollutant emissions from new motor vehicles through section 202(a)(1) emissions standards for new motor vehicles, as opposed to section 211(c)(1) fuel and fuel additive regulations. At the present time, the EPA has no plans to regulate emissions from new motor vehicles of carbon dioxide or any other greenhouse gases under either section 202(a)(1) or section 202(1)(2) of the Clean Air Act.

\section{State and Local Government Regulation of Emissions of Hazardous Air Pollutants From Motor Vehicles}

States and their political subdivisions are preempted by section 209(a) ${ }^{334}$ of the Clean Air Act from adopting or attempting to enforce any standard relating to the control of emissions of hazardous air pollutants from new motor vehicles or new motor vehicle engines, although the EPA Administrator would have the authority under section 209(b) ${ }^{335}$ to grant the state of California a waiver of this preemption. If California was granted such a waiver, another state which has section 110 state implementation plan provisions approved under the provisions of Part D of the Clean Air Act for nonattainment areas would be permitted to adopt hazardous air pollutant standards for a particular model year's new motor vehicles or new motor vehicle engines if the standards are identical to California standards for which a waiver has been granted. $^{336}$

Section $116^{337}$ of the Clean Air Act would authorize a state or political subdivision of a state to adopt and enforce standards or limitations for control of emissions of hazardous air pollutants from in-use on-road motor vehicles.

\section{CONCLUSION}

The EPA Administrator should reverse his ruling that carbon dioxide and other greenhouse gases are not "air pollutants" whose emissions can be regulated under the Clean Air Act. Furthermore, the EPA Administrator should proceed to issue regulations under either section 202(a)(1) or section

333. Sierra Club v. Johnson, No. 04-CV-00094 (D.D.C. July 22, 2005). This consent decree is discussed in Cook, supra note 16.

334. 42 U.S.C. $\$ 7543(a)$.

335. Id. at $\S 7543(\mathrm{~b})$

336. Id. at $\S 7507$ (a).

337. Id. at $\S 7416$. 
202(1)(2) of the Clean Air Act to reduce the emissions of carbon dioxide and other greenhouse gases from new motor vehicles and new motor vehicle engines. These regulations could be fuel economy standards that are stricter than the present CAFE standards under the Energy Policy and Conservation Act, but also could be standards identical to, or modeled after, California's greenhouse gases emission reduction regulations for new motor vehicles. In addition, the EPA Administrator should grant a waiver under section 209(b)(1) of the Clean Air Act so that these California state regulations will not be preempted by either section 209(a) of the Clean Air Act or by the CAFE standards of the EPCA.

Regardless of whether the EPA Administrator takes these actions under the Clean Air Act to reduce emissions of carbon dioxide and other greenhouse gases from new motor vehicles and new motor vehicle engines, the EPA Administrator should proceed to adopt regulations under section 202(1)(2) of the Clean Air Act to reduce emissions of toxic and hazardous air pollutants from new motor vehicles, and states should consider adoption of reasonable regulations to reduce greenhouse gas emissions from in-use on-road motor vehicles. 